\title{
Business and Human Rights After Ruggie: Foundations, the Art of Simplification and the Imperative of Cumulative Progress*
}

\author{
Radu Mares* \\ in \\ R. Mares (ed.), The UN Guiding Principles on Business and Human Rights - Foundations and \\ Implementation, Martinus Nijhoff Publishers (Leiden, Boston 2012) pp. 1-50
}

\section{Introduction}

The United Nations (UN) Special Representative of the Secretary-General (SRSG) on the Issue of Human Rights and Transnational Corporations and Other Business Enterprises has now concluded his work.

Professor John Ruggie who was entrusted with the SRSG mandate expects his work, laying down the needed foundational work and now carrying the authority of the Human Rights Council (HRC), to mark 'the end of the beginning': the "Council endorsement of the Guiding Principles, by itself, will not bring business and human rights challenges to an end. But it will mark the end of the beginning: by establishing a common global platform for action, on which cumulative progress can be built, step-by-step, without foreclosing any other promising longer-term developments." Let us hope that this 'end of the beginning' paraphrase of Churchill after the crucial El Alamein battle will mark a turning point in business and human rights as it did in WWII. $^{2}$

The HRC endorsed unanimously Ruggie's reports, first in 2008 and finally in 2011. This marks a breakthrough in itself by being the first time the UN member states adopted a common position laying down standards of expected behaviour from business with regard to human rights. This mandate on business and human rights (2005-2011) came on the heels of an ill-fated standardsetting effort in the UN - the Draft Norms (1998-2004). ${ }^{3}$ While the Norms chose a more direct path to corporate accountability, to a large extent relying on international treaties and monitoring, and national regulations, the SRSG conceived a broader and less centralised template aimed at leveraging the responsibilities and roles of various social actors and relying on legal and other rationalities to move markets towards a more socially sustainable path.

\footnotetext{
* This is the final version of the chapter. For references to exact pages, please refer either to this on-line document or to the formatted version in the book.

* Senior researcher, Raoul Wallenberg Institute of Human Rights and Humanitarian Law, Lund, Sweden.

${ }^{1}$ Guiding Principles on Business and Human Rights: Implementing the United Nations 'Protect, Respect and Remedy' Framework, A/HRC/17/31, 2011, para. 13 (hereinafter 'Guiding Principles').

${ }^{2}$ Churchill said: "This is not the end. It is not even the beginning of the end. But it is, perhaps, the end of the beginning.” W. Churchill, 'The End of the Beginning', The Lord Mayor's Luncheon, Mansion House, 10 November 1942, <www.churchill-society-london.org.uk/EndoBegn.html>.

${ }^{3}$ Norms on the Responsibilities of Transnational Corporations and Other Business Enterprises with regard to Human Rights 2003, UN Doc. E/CN.4/Sub.2/2003/12/Rev.2 (hereinafter 'Draft Norms').
} 
This represents an exciting moment for the debates on corporate social responsibility (CSR): two different visions of social change and global governance are on the table. The Draft Norms' more traditional state-centric, international law-based approach meets the less centralised, governancebased outlook of the SRSG. In an unavoidably multifaceted treatment to the issue of corporate accountability, the two diverging visions rely, not surprisingly, on many common elements and building blocks that were however arranged and balanced differently. Ruggie went for a strategy of preparing a siege instead of leading a cavalry charge.

This volume aims to capture this moment in time: a moment of tacking stock of a successfully concluded mandate and of preparing for the massive task of following-up with more operational guidance, more detailed standards, more effective governance mechanisms and more finely grained conceptual treatments. It is a book delving into what the contributors perceive as the accomplishments of a mandate as well as its deficiencies and outstanding issues. The chapters that follow offer a detailed though selective treatment of the SRSG's work, with a special emphasis on its regulatory and governance features and implications.

The SRSG work, with the 'Protect, Respect and Remedy' Framework (2008) and Guiding Principles (2011) as its peak, is multilayered and comprehensive. Instead of a dry, tedious description this introductory chapter will give the floor often to the SRSG: readers will find numerous quotations and references that will allow him or her to follow Ruggie's reasoning. Ruggie should be commended for the way he explained many of his choices through accessiblywritten reports, working papers, academic journal articles, speeches, interviews and private exchanges with countless individuals. Many of these documents will be referenced herein. Annex 1 to this introduction lists all the SRSG reports for easy reference. The intention here is to provide some context to the arguments contributors to this volume make and emphasise some issues of special relevance to those interested in a regulatory and governance perspective on CSR.

Although Ruggie has refused to call for an encompassing treaty on business and human rights and he concluded that businesses currently do not have legal obligations under international human rights law (IHRL), it would be a grave mistake to overlook his work as of marginal relevance to legal academics and professionals, to presume that his thinking was not informed by law. Instead there is a wealth of materials, analyses and entry points for lawyers interested in international law, human rights law, criminal law, company law, securities law, investment law, transparency laws and law of contracts. Also the broader issue of what role the law could and should play in international governance and in complex regulatory regimes is at the core of Ruggie's work.

\section{Mandate}

Ruggie was appointed SRSG following the stalemate in the Commission on Human Rights in 2004. After the Sub-Commission on the Promotion and Protection of Human Rights submitted the Draft Norms to the Commission, the later decided not to endorse them; instead it asked the UN High Commissioner for Human Rights to conduct an in-depth study on "the scope and legal status of existing initiatives and standards" relating to the corporate responsibilities with regard 
to human rights. ${ }^{4}$ Following the receipt of that study, ${ }^{5}$ the Commission decided to set up the SRSG mandate for a two-year period, later prolonged with a third year. That mandate asked the SRSG to identify standards of corporate responsibility, to clarify often used CSR concepts such as 'complicity' and 'sphere of influence', to focus on human rights impact assessments, to compile best practices of states and corporations, and to elaborate on the regulating role of states. ${ }^{6}$

In 2008, Ruggie presented the 'Protect, Respect, Remedy' Framework. The Human Rights Council, which has replaced the Commission on Human Rights in 2006, endorsed unanimously the Framework and asked the SRSG to continue his work for another three years. The new mandate required him, among other issues, to provide concrete guidance regarding the obligations of states and responsibilities of businesses, to elaborate on the scope and content of corporate responsibility, to explore effective remedies to corporate abuses, and to continue his work in a broadly consultative manner. ${ }^{7}$

In 2011, Ruggie concluded his work by issuing the Guiding Principles, a set of 31 recommendations containing foundational and operational principles. The HRC adopted unanimously this document and also decided the follow-up to the SRSG mandate. ${ }^{8}$ Thus a multistakeholder-forum on business and human rights will meet annually and a Working Group of five experts will be established for a three-year period with a multitude of tasks: dissemination, promoting implementation, best practice identification, capacity-building, country visits, recommendations on access to remedies, and dialogue and cooperation with relevant actors. ${ }^{9}$

\section{Framework and Guiding Principles}

The 'Protect, Respect, Remedy' Framework can be succinctly summarised, in Ruggie's own words, as follows:

The Framework rests on three pillars. The first is the State duty to protect against human rights abuses by third parties, including business enterprises, through appropriate policies, regulation, and adjudication. The second is the corporate responsibility to respect human rights, which means that business enterprises should act with due diligence to avoid infringing on the rights of others and to address adverse impacts with which they are involved. The third is the need for greater access by victims to effective remedy, both judicial and non-judicial. Each pillar is an essential component in an inter-related and dynamic system of preventative and remedial measures: the State duty to protect because it lies at the very core of the international human rights regime; the corporate responsibility to respect because it is the basic

\footnotetext{
${ }^{4}$ Commission on Human Rights, Responsibilities of transnational corporations and related business enterprises with regard to human rights, Decision 2004/116.

${ }^{5}$ Report of the United Nations High Commissioner on Human Rights on the responsibilities of transnational corporations and related business enterprises with regard to human rights, E/CN.4/2005/91, 2005.

${ }^{6}$ Commission on Human Rights, Human rights and transnational corporations and other business enterprises, Resolution 2005/69, 2005.

${ }^{7}$ Human Rights Council, Mandate of the Special Representative of the Secretary-General on the issue of human rights and transnational corporations and other business enterprises, Resolution 8/7, 2008.

${ }^{8}$ Human Rights Council, Human rights and transnational corporations and other business enterprises, A/HRC/17/L.17/Rev.1, 2011.

${ }^{9}$ Ibid.
} 
expectation society has of business in relation to human rights; and access to remedy because even the most concerted efforts cannot prevent all abuse. ${ }^{10}$

Specifically on corporate responsibilities, the responsibility to respect (RtR) contained in Pillar 2 calls for "an ongoing process of human rights due diligence, whereby companies become aware of, prevent, and mitigate adverse human rights impacts. The four core elements of human rights due diligence [are]: having a human rights policy, assessing human rights impacts of company activities, integrating those values and findings into corporate cultures and management systems, and tracking as well as reporting performance."

The normative orientation of the RtR is provided by international law standards. In explaining which rights the due diligence process should encompass, Ruggie wrote:

The answer is simple - in principle, all internationally recognized human rights ... because companies can affect the entire spectrum of rights ... [C]ompanies at a minimum should look to the International Bill of Human Rights - the Universal Declaration and the two Covenants - as well as the ILO Declaration on Fundamental Principles and Rights at Work. They should do so for two reasons. First, the principles these instruments embody are the most universally agreed upon by the international community. Second, they are the main benchmarks against which other social actors judge the human rights impacts of companies. $^{12}$

\section{Approach and Results of the SRSG Mandate}

In the pursuit of his 2005 mandate, Ruggie set himself to deliver not an international code of conduct containing corporate responsibilities and an implementation mechanism. Instead he conceived a broader framework able, in the words of the High Commissioner for Human Rights, "to guide the understanding of, as well as responses to, the issue of business and human rights". 13 His premise has been that

The root cause of the business and human rights predicament today lies in the governance gaps created by globalization - between the scope and impact of economic forces and actors, and the capacity of societies to manage their adverse consequences. These governance gaps provide the permissive environment for wrongful acts by companies of all kinds without adequate sanctioning or reparation. How to narrow and ultimately bridge the gaps in relation to human rights is our fundamental challenge. ${ }^{14}$

In his effort to challenge that 'permissive environment' Ruggie demonstrated his ability to simplify and reframe CSR discussions. 'Simplify' because he appears to have extracted three key aspects (the three 'pillars') that have been familiar in CSR debates, structured the analysis around them and got the acceptance of key stakeholders. ${ }^{15}$ As it often happens, the devil is in the

\footnotetext{
${ }^{10}$ Guiding Principles, supra note 1, para. 6.

11 Business and human rights: Towards operationalizing the 'protect, respect and remedy' framework, A/HRC/11/13, 2009, para. 49 (hereinafter 'Towards operationalizing').

${ }^{12}$ Ibid., paras. 52-54.

${ }^{13}$ N. Pillay (United Nations High Commissioner for Human Rights), 'The Corporate Responsibility to Respect: A Human Rights Milestone', Annual Labour and Social Policy Review (2008), <www.ohchr.org/Documents/Press/HC_contribution_on_Business_and_HR.pdf>.

14 Protect, Respect and Remedy: a Framework for Business and Human Rights, A/HRC/8/5, 2008, para. 3 (hereinafter 'Protect, Respect and Remedy').

${ }^{15}$ See the chapter by Melish and Meidinger in this volume, arguing in favour of a forth pillar - the 'Participate' pillar - that Ruggie should have recognised.
} 
details, where controversies erupted and will linger on. However this simplification and streamlining has been important in securing the buy-in for the Framework from diverse stakeholders. Ruggie himself wrote about his pursuit for a shared understanding and securing support from various constituencies: ${ }^{16}$

Two main achievements are widely attributed to the SRSG's mandate:

1. Generating a profound shift in the dynamic of the business and human rights debate, from deep polarization among stakeholder groups in 2005 to a greater shared understanding of business and human rights challenges;

2. Securing wide multi-stakeholder support for the 'Protect, Respect and Remedy' Framework and the Guiding Principles for its implementation as the foundation for better managing those challenges going forward. ${ }^{17}$

A prime example of reframing is the well-known state obligation to protect human rights. ${ }^{18} \mathrm{By}$ offering a Framework instead of a code of conduct, Ruggie ensured that the CSR discussion is not carried in a vacuum. There is a difference in emphasis which reflects different thinking: while most other CSR instruments affirm and stress in the preamble and first article the obligations of states under international human rights law, ${ }^{19}$ the rest of the text tends to be devoted to corporate responsibilities. Ruggie employed a different structure: state duties and corporate responsibilities would both be 'pillars' under a construction that stands precariously if a pillar is too weak. In other words, treatments of CSR that do not lose sight of the duties and roles of states have more potential to solve human rights problems in practice. Furthermore, in the economy of the SRSG reports, each pillar takes quite an equal space; there is no imbalance here either. In addition, not only are the duties of states restated, but they are detailed to point at inconsistencies in state practice, ${ }^{20}$ they cover both host and home states of multinational enterprises (MNEs), and they account for states as both regulators and economic actors. This reframing and comprehensiveness pays dividends: the result is a governance template that discusses responsibilities and roles and aims to prompt diverse actors into (concerted) action. Ruggie strives to leverage influence from different quarters by showing how inaction, inconsistencies and irresponsibility feed on each other to allow impunity.

Linked to the task of securing stakeholder buy-in, Ruggie employed a participatory approach throughout his mandates. He has arranged seminars, conferences, field studies and other engagement avenues that he used to collect views and communicate his work. ${ }^{21}$ Make no

\footnotetext{
${ }_{17}^{16}$ See especially the chapter by Parker and Howe in this volume, analysing Ruggie's diplomatic project.

${ }^{17}$ Recommendations on Follow-Up to the Mandate, Mandate of the Special Representative of the Secretary-General (SRSG) on the Issue of Human Rights and Transnational Corporations and other Business Enterprises, 2011, <www.business-humanrights.org/media/documents/ruggie/ruggie-special-mandate-follow-up-11-feb-2011.pdf>.

${ }^{18}$ For a discussion about the nature of a state's obligation to protect, see M. Hakimi, 'State Bystander Responsibility', 21:2 The European Journal of International Law (2010) pp. 341-385.

19 For example, the Draft Norms read: "States have the primary responsibility to promote, secure the fulfilment of, respect, ensure respect of, and protect human rights recognised in international as well as national law, including assuring that transnational corporations and other business enterprises respect human rights.” Draft Norms, supra note 3 , para. 1.

${ }^{20}$ Ruggie referred to "“vertical' incoherence, where governments take on human rights commitments without regard to implementation; and 'horizontal' incoherence, where departments - such as trade, investment promotion, development, foreign affairs - work at cross purposes with the State's human rights obligations and the agencies charged with implementing them." Protect, Respect and Remedy, supra note 14, para. 33.

${ }^{21}$ See the chapter by Buhmann in this volume detailing the participatory process throughout the SRSG mandate.
} 
mistake, this approach was also clearly outlined in the UN mandate as a reaction to some criticisms that the Draft Norms process had received. ${ }^{22}$ Furthermore, Ruggie networked widely and commissioned studies from various organisations, law firms and experts in an attempt to leverage expertise on punctual issues. ${ }^{23}$ This approach has generated a remarkable effervescency and engagement in the legal community, for example. Finally, Ruggie engaged with countless individuals, critics and supporters alike, through open letters or private exchanges. At the end of his mandate the HRC commended Ruggie for "the broad range of activities undertaken ..., including in particular the comprehensive, transparent and inclusive consultations conducted with relevant and interested actors in all regions". ${ }^{24}$ Echoing this perception, the European Union stated that "there is no doubt that the success results from the inclusive approach of a process where States, business actors and civil society were fully associated". 25

Ruggie has made a deliberate push to key organisations in an effort to scale up the impacts of his work in the UN. ${ }^{26}$ Notable has been his promotion of the human rights 'due diligence' idea to the Organization for Economic Co-operation and Development (OECD), the World Bank's International Financial Corporation (IFC) and the European Commission (EC). All these organisations had CSR policy instruments preceding the SRSG mandate; these instruments have or will be updated in light of the SRSG work. Ruggie also influenced the International Organisation for Standardisation (ISO) as it was preparing its first Guidance on social responsibility, the ISO 26000, which is an important document given the ISO's broad reach into the business community.

Ruggie defined his approach as a "principled form of pragmatism: an unflinching commitment to the principle of strengthening the promotion and protection of human rights as it relates to business, coupled with a pragmatic attachment to what works best in creating change where it matters most - in the daily lives of people". ${ }^{27}$ It is in relation to principled pragmatism where the discussion of policy choices and surrounding controversies fits in: Should Ruggie have proposed to the HRC the pursuit of an international treaty on CSR? Should he have maintained that companies have legal responsibilities under IHRL? Should corporate responsibilities extend beyond 'respecting' towards 'securing' human rights? Do states have an obligation to reach extraterritorially as part of their duty to protect against corporate abuses? It is now clear that the element of pragmatism has been vindicated by the HRC's unanimous endorsements in 2008 and 2011. But the principled part will be unmistakably dependent on how effective Ruggie's strategy

\footnotetext{
${ }^{22}$ Commission on Human Rights, supra note 6, para. 3.

${ }^{23}$ See the SRSG website at <www.business-humanrights.org/SpecialRepPortal/Home>.

${ }^{24}$ Human Rights Council, Human rights and transnational corporations and other business enterprises, A/HRC/RES/17/4, 2011.

${ }^{25}$ EU comments on the draft Guiding Principles for the implementation of the UN 'Protect, Respect, Remedy' Framework, D(2011) 702 246, 31 January 2011, <ec.europa.eu/enterprise/policies/sustainablebusiness/files/business-human-rights/eu_statement_final_en.pdf >.

${ }^{26}$ Ruggie said: “At the same time as I've been working through UN, I've also been working with a number of other international institutions to make sure that their policies become aligned with the UN Framework and Guiding Principles ... It is important for such convergence to take place, and because it makes it more likely that there will be a level playing field for all." 'Business and Human Rights: Together At Last?', A Conversation with John Ruggie, Fletcher Forum of World Affairs, Summer 2011, pp. 121-122.

${ }^{27}$ Interim Report of the Special Representative of the Secretary-General on the Issue of Human Rights and Transnational Corporations and Other Business Enterprises, E/CN.4/2006/97, 2006, para. 81 (hereinafter 'Interim Report').
} 
of change will prove to be, as Ruggie himself rightly noted in his sobering 'end of the beginning' remarks. $^{28}$

Ruggie has enriched the field of business and human rights as a result of his six-year mandate. This is partly due to him not shying away from controversy; his choices and explanations have offered at least a reasoned reference point for supporters and dissenters to reflect upon. He came forward with painstaking explanations when, for example, he dismissed the conceptual approach taken by the Draft Norms or when he refused to call for a encompassing treaty on CSR. The battle of ideas could only benefit from such opportunities for frank and reasoned discussions, which are bound to continue after the mandate was concluded. In connection with this, the SRSG reports sometime strike as models of learned yet accessibly-written argumentation. While all sides - Ruggie and his diverse contestants - agreed that individuals everywhere require better protection against human rights abuses occurring in business operations, Ruggie's elaborations presented with unprecedented clarity some tensions, complexities and choices. While various actors predictably and legitimately disagree on some of the choices made in the Framework and General Principles, there is little doubt that the business and human rights discourse is now at another level than it was in 2005.

Another contributor to Ruggie's 'enrichment' legacy in the field has to do with the broad governance outlook he adopted. Ruggie sought to identify key tensions crisscrossing the CSR body, and to impress a system of interlocking roles and responsibilities. Getting hold conceptually of such a polycentric governance model is significantly more complicated than the state-centric, treaty-driven model offered by the Draft Norms. Ruggie did not offer, neither could he within the format of the SRSG reports, a fine-grained model of governance in the CSR area. He limited himself to discard, impress and outline. Delving deeper into the dynamics of CSR regimes to understand their functioning and how to design for effectiveness is surely the next step if governance-based conceptualisations of CSR are to deliver on their promise. As Ruggie decided to remain involved with the business and human rights field after the conclusion of his mandate, including writing a book, it is hoped that he will refine further the polycentric governance regime in the business and human rights area. ${ }^{29}$

In a few years Ruggie developed a broad portfolio of materials that could be readily accessed and referenced to support and clarify his position. ${ }^{30} \mathrm{He}$ has methodically covered punctual issues through his reports, addendums, scholarly articles, conference speeches, interviews, and commissioned studies from prestigious organisations. Based on this approach, Ruggie's credentials as a top thinker in his academic field, ${ }^{31}$ his experience in high positions in the UN allowing for navigation of the treacherous currents in the $\mathrm{UN},{ }^{32}$ his astonishing energy of making contact with diverse audiences, and the counter-instinctive fit of a political scientist asked to

\footnotetext{
${ }^{28}$ See text associated with supra note 1.

${ }^{29}$ J. G. Ruggie, Post-Mandate Plans, 18 July 2011, <business-humanrights.org/media/documents/ruggie/ruggiepost-mandate-plans-18-jul-2011.pdf>.

${ }^{30}$ See Annex 1 in this chapter for his reports, and the SRSG website (supra note 23) for additional studies commissioned or submitted during the SRSG mandate.

${ }^{31}$ See the chapter by Melish and Meidinger in this volume where they discuss Ruggie's background and his sociological institutionalist approach to system transformation.

${ }^{32}$ Ruggie served as Assistant Secretary-General and Chief Adviser for strategic planning to UN Secretary-General Kofi Anann (1997-2001).
} 
bring clarity to a domain - human rights - traditionally occupied by lawyers have all conspired to deliver through the last six years the first UN-endorsed global instrument on business and human rights and the most advanced conceptual elaboration on business and human rights carried out in an international governmental organisation to date.

\section{Draft Norms versus Framework: Between Polarisation and Similarities}

As mentioned before, the SRSG mandate was set up because work on the Draft Norms came to a standstill as business opposition intensified and state support in the Commission on Human Rights proved to be lacking. Non-governmental organisations (NGOs) championed the Draft Norms for a few key reasons: the promise of legally binding obligations on business, through an international treaty and subsequently national laws; the sweeping obligations on companies expected not only to 'respect' human rights, but to 'promote', 'protect', 'secure' and 'ensure respect' of human rights; ${ }^{33}$ and the monitoring and verification to be provided by international organisations, such as the UN, and national mechanisms. ${ }^{34}$ Although nobody - including the drafters and supporting NGOs - harboured any doubts that the Draft Norms were a work in progress that required further refinement, they sensed the importance of kick-starting an international rule-making process to hold companies accountable. To put it differently, no matter the possible shortcomings of the Norms initial draft in concept or formulation, they would pale in comparison with the importance of kick-starting the process.

Ruggie however was concerned, policymaking-wise, by the states' lack of willingness to adopt and then to actually enforce an international legal instrument. Concept-wise, he was critical in regard to the perceived lack of foundations, boundaries and specificity characterising the Draft Norms' approach to corporate responsibilities. In this regard Ruggie explained extensively his decision to dismiss the Norms; he questioned, among other aspects, why different actors would have similar sweeping obligations ${ }^{35}$ and how the resulting overlap of state and corporate obligations would affect the governance system. ${ }^{36}$ These aspects, Ruggie felt, have derailed the Draft Norms and would do so again with regard to his mandate. ${ }^{37}$ If the Norms process was actually delivering just an illusion, Ruggie chose to outline what he thought could conceptually and feasibly move the debate closer to a path of improved business practices and ultimately accountability for rights violations. Ruggie summarised well the interests of some key stakeholders in the controversy surrounding the Draft Norms:

\footnotetext{
${ }^{33}$ Draft Norms, para. 1, supra note 3.

${ }^{34}$ Ibid., paras. 15-17.

${ }^{35}$ Ruggie drew attention that “[w]hile corporations may be considered 'organs of society', they are specialized economic organs, not democratic public interest institutions. As such, their responsibilities cannot and should not simply mirror the duties of States." Protect, Respect and Remedy, supra note 14, para. 53.

${ }^{36}$ The overlap of responsibilities would invite "endless strategic gaming by states and companies alike". Interim Report, supra note 27, para. 68. Further Ruggie wrote: "The corporate responsibility to respect exists independently of States' duties. Therefore, there is no need for the slippery distinction between 'primary' State and 'secondary' corporate obligations - which in any event would invite endless strategic gaming on the ground about who is responsible for what." Protect, Respect and Remedy, supra note 14, para. 55.

${ }^{37}$ Ruggie outlines in detail the conceptual flaws of the Draft Norms, as he perceived them, in J. G. Ruggie, 'Business and Human Rights - The Evolving International Agenda', American Journal of International Law (2007) p. 822. (hereinafter 'Evolving Agenda').
} 
It would be surprising if all major actors in the 'Norms' debate, quite apart from the substantive merits of their arguments, did not also behave strategically, in keeping with their perceived interests. Business typically dislikes binding regulations until it sees their necessity or inevitability. Governments often support the preferences of corporations domiciled in their countries and/or compete for foreign investment. And the imprimatur of 'UN Norms' would have provided NGOs with a powerful campaign tool: declaring certain corporate acts to be 'illegal' has far greater social purchase, even in the absence of viable enforcement mechanisms, than merely claiming corporate 'wrongdoing. ${ }^{38}$

The fate of the Draft Norms continues to polarise writers almost a decade after their peak in $2004,{ }^{39}$ including contributors to this volume. The Norms versus Ruggie controversy is fading in importance, particularly now that the SRSG project was endorsed by the HRC while the Norms were not. Also the thinking behind the SRSG approach has been refined and presented in much more detail than the drafters of the Norms had or could have done. In the same time, and without overlooking the fundamental disagreement on the social change process at hand, there are some surprising similarities that invite us to leave behind some of the controversy.

For example, the Draft Norms mention the 'due diligence' concept that came to define Ruggie's approach to corporate responsibilities. The Commentary to the Norms reads: "Transnational corporations and other business enterprises shall have the responsibility to use due diligence in ensuring that their activities do not contribute directly or indirectly to human abuses ..."40 Further elaboration of what due diligence entails has been welcomed both by Ruggie himself ${ }^{41}$ and by supporters of the Norms. ${ }^{42}$ Another commonality revolves around the value of transparency. While the Norms expected businesses to 'periodically report' on the implementation of the Norms (paragraph 15), Ruggie expects companies to 'know and show' that they respect human rights (Guiding Principle No. 21). Finally, although the role of law seems to be the supreme polariser in the Norms-Ruggie debate, a more nuanced understanding is needed. As a later section will show, Ruggie did not endorse an international and overarching legal instrument on CSR at this moment in time, while he explicitly affirmed the necessity or at least encouraged states to consider a specific international treaty (on international crimes), national laws in various fields, and that all these interventions are called for now. In the coming years it will be important to attempt to focus on such commonalities between the Norms and the Framework without obscuring their different visions of social change and the role of law in the process.

\footnotetext{
${ }^{38}$ Ibid., p. 822.

${ }^{39}$ The OHCHR summarised in 2005 the main arguments against and in favour of the Draft Norms. Report of the High Commissioner, supra note 5, paras. 20-21.

${ }^{40}$ Commentary for the Norms on the Responsibilities of Transnational Corporations and Other Business Enterprises with Regard to Human Rights, E/CN.4/Sub.2/2003/38 (2003), para. A.1.b),

<www1.umn.edu/humanrts/links/CommentApril2003.html>.

${ }^{41}$ Ruggie wrote: "Had the Norms exercise confined itself to compiling such an inventory [of human rights instruments], coupled with a set of benchmarks of what practices business must or should avoid, and what it could help to achieve, the subsequent debate might have focused on substantive issues: What belongs on the list, what doesn't, and why? What are the different categories of business responsibilities, ranging from the mandatory to the desirable? How can broad principles best be translated into management practices and tools? In short, the relevant stakeholders might well have focused on the sorts of operational issues that have been taken up by a group of ten companies known as the Business Leaders for International Human Rights (BLIHR), which are engaged in a constructive effort to explore whether and how some of the concrete provisions of the Norms can be turned into company policies, processes and procedures." Interim Report, supra note 27, paras. 57-58.

${ }^{42}$ The chapter by Sullivan and Hachez in this volume indicates that there is value in re-using the Draft Norms' orientation in the guise of the BLIHR's detailed list of corporate responsibilities.
} 


\section{Ruggie on Voluntarism}

Ruggie's opinion on corporate voluntarism cannot be deduced from two of his decisions that antagonised many NGOs: international law does not currently impose legal obligations on companies, ${ }^{43}$ and the SRSG will not recommend the HRC to pursue an international treaty laying down corporate obligations. Indeed, on a number of occasions Ruggie made explicit remarks about the potential as well as the inherent limits of corporate voluntarism and multistakeholder CSR initiatives. ${ }^{44}$

The inherent limits of voluntarism have to do with participation and accountability and are wellknown: voluntary approaches alone cannot coerce unwilling companies to adopt CSR policies or to join multistakeholder initiatives; neither could they thereafter force companies to abide by their stated CSR commitments. To achieve uniform coverage and coercion, law has a privileged position due to its unique ability to systematically tackle wrongdoers. As Ruggie wrote, "[a]t the risk of sounding like a heretic, I would contend that private governance arrangements, no matter how successful, can take us only so far. They will remain relatively small islands of progress unless their achievements are rooted in, and generalized through, the sphere of public

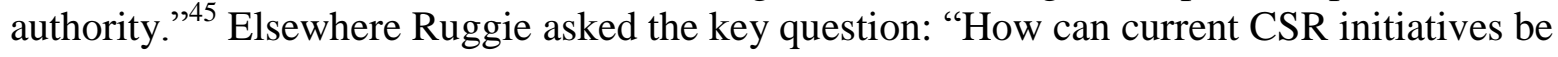
scaled up and connected, in order to establish an interlocking network of regulatory instruments and governance structures?" In a sobering view of the limits of CSR he remarked:

At the end of the day, none of these efforts of aggregation and leveraging can be successful without governments, because governments are the global embodiment of representative politics. Yet, at the same time, when devising strategies for change, it is not always wise to begin with governments. Now that I am no longer at the UN, I can confess to that heretical thought. ${ }^{46}$

\section{Ruggie on Law}

Ruggie stated that he understood that his "mandate is intended to be primarily evidence based". ${ }^{47}$ Through the years he took note of laws and contracts, both of which create legal obligations for businesses. He covered numerous bodies of law at national and international levels. There are recent legal developments of high relevance to human rights and a few should be succinctly discussed here.

\subsection{Recent Legal Developments}

\footnotetext{
${ }^{43}$ For an analysis of corporate responsibilities under international human rights law, see the chapter by Knox in this volume.

${ }^{44}$ For examples of corporate voluntarism, see United Nations Global Compact and Office of the High Commissioner of Human Rights, Embedding Human Rights in Business Practice, 3 volumes (2004, 2007, 2009).

${ }^{45}$ J. G. Ruggie, The Global Compact and the Challenges of Global Governance, Annual Meeting, Global Compact Learning Forum, 11-13 December 2002, p. 3. See also R. Mares, The Dynamics of Corporate Social Responsibilities (Martinus Nijhoff Publishers, 2008) pp. 158-164.

${ }^{46}$ Carnegie Council on Ethics and International Affairs, The Impact of Corporations on Global Governance, A Report of the Empire and Democracy Project (Carnegie Council, New York, 2004), pp. 11 and 23.

${ }^{47}$ Interim Report, supra note 27, para. 7. "But insofar as it involves assessing difficult situations that are themselves in flux, it inevitably will also entail making normative judgments. In the SRSG's case, the basis for those judgments might best be described as a principled form of pragmatism ..." Ibid., para. 81.
} 
Ruggie concurs with an assessment of globalisation often voiced in civil society circles. He acknowledged that "the backlash [against globalization and global market integration] is triggered by a growing imbalance in global rule making. Those rules that favour global market expansion have become more robust and enforceable ... [b]ut rules intended to promote equally valid social objectives, be they labor standards, human rights, environmental quality or poverty reduction, lag behind and in some instances actually have become weaker." ${ }^{48}$

\subsubsection{Transparency}

The bulk of recent laws adopted at national level aim to enhance transparency; corporations are required to disclose information on various aspects of their operations with direct or indirect implications for human rights. For example, the Dodd-Frank Act (2010) in the US has two relevant sections. ${ }^{49}$ Section 1502 refers to conflict minerals that are used to finance violent conflicts in the Democratic Republic of Congo (DRC). It asks companies to disclose annually whether their products are 'DRC conflict free' or not, and to describe the due diligence measures the company takes to track such minerals in its supply chain. Preliminary data indicates the dramatic effect of this transparency law. ${ }^{50}$ Section 1504 requires extractive companies (oil, natural gas and minerals) to disclose the payments (taxes, royalties, license fees, production entitlements and bonuses) they make to foreign governments. ${ }^{51}$ This allows investors to assess better the risks entailed by their investments. ${ }^{52}$ The Securities and Exchange Commission (SEC) is about to issue detailed rules for implementing the law. ${ }^{53}$

\footnotetext{
48 J. G. Ruggie, 'Taking Embedded Liberalism Global: The Corporate Connection', in J. G. Ruggie (ed.), Embedding Global markets: An Enduring Challenge (Ashgate, 2008) p. 234 (reference omitted).

${ }^{49}$ Dodd-Frank Wall Street Reform and Consumer Protection Act (2010).

${ }^{50}$ A World Bank source reported that "[a]lmost everything came to a standstill" following the passage of the US law. "Increased scrutiny of companies working in the region has caused mineral buyers including Traxys SA, Malaysia Smelting Corp. and Amalgamated Metals Plc to curtail or eliminate their purchases, and most trade from eastern Congo ground to a halt April 1. That month, electronics-industry groups implemented new guidelines for mineral smelters to ensure their products were 'conflict-free'." M. J. Kavanagh, 'Congo Government Asks U.S. to Use OECD Guidance for Conflict-Mineral Rules', Bloomberg, 28 July 2011, <www.bloomberg.com/news/2011-0728/congo-government-asks-u-s-to-use-oecd-guidance-for-conflict-mineral-rules.html>; Motorola: "The law created a de facto ban on minerals in the Congo." J. Bardelline, 'Motorola Seeks a Conflict-Free Electronics Supply Chain in the DRC', Greenbiz, 12 July 2011, <www.greenbiz.com/news/2011/07/12/motorola-seeks-conflict-freeelectronics-supply-chain-drc>.

${ }^{51}$ K. M. Martorana, Legislating Transparency in the Extractive Sector: Will the Securities and Exchange Commission take the lead?, Oxfam America, 12 July 2011, <www.policyinnovations.org/ideas/innovations/data/000196>.

${ }^{52}$ For how investors factor tax information in their decisions, see C.t Investments, Materiality of disclosure required by the Energy Security through Transparency Act, 2010, <www.calvert.com/NRC/literature/documents/10003.pdf>.

${ }^{53}$ See the debate before the SEC with diverging submissions asking the SEC to require detailed data, as NGOs and some institutional investors prefer, or more aggregated data, as the industry argues. Examples of the former position are Revenue Watch International (K. Lissakers, Submission to SEC, 6 December 2010) and Calvert Asset Management Company (B. Freeman et al., Submission to SEC, 15 November 2010). Examples of the latter position come from Shell (Submission by M. J. ten Brink, Executive Vice President Controller, Royal Dutch Shell plc, 25 October 2010) and American Petroleum Institute (Submission by K. Isakower and P. Mulva, 9 December 2010). All submissions are available on the SEC website, Specialized Disclosures: Title XV Provisions of the Dodd-Frank Wall Street Reform and Consumer Protection Act, <www.sec.gov/comments/df-title-xv/specializeddisclosures/specialized-disclosures.shtml>.
} 
Along the same lines, California adopted in 2010 a law requiring disclosures on goods tainted with slavery and human trafficking. The law states that "[c]onsumers and businesses are inadvertently promoting and sanctioning these crimes through the purchase of goods and products that have been tainted in the supply chain". Therefore it requires "retail sellers and manufacturers doing business in the state to disclose their efforts to eradicate slavery and human trafficking from their direct supply chains ...".54 Stronger yet is the EC approach to combat illegal logging by tackling the trade in illegally harvested wood. The regulation to come in force in 2013 imposes a traceability obligation on traders and a due diligence system on operators to prohibit entry. ${ }^{55}$

The European Union (EU) has endorsed Ruggie's Framework and Guiding Principles and emphasised that it "was highly supportive from the outset". 56 The European Commission is currently considering amending the Directive on annual and consolidated accounts ${ }^{57}$ to enhance the disclosure of non-financial information by enterprises. ${ }^{58} \mathrm{~A}$ recent, large report from the EC wrote: "For public policy, when a company is obliged, coaxed or encouraged to report on its CSR activities, it is a key means of 'leveraging' more CSR."59

\subsubsection{Company Law and the Corporate Governance}

Transparency, augmented by 'comply or explain' requirements, has been a trademark of the corporate governance area. ${ }^{60}$ This approach was introduced first in the UK. Since 1993, companies listed on the London Stock Exchange are required to include in annual reports a narrative statement of how they apply the principles of the 'Combined Code'. The 'comply or explain' provision requires a statement as to whether or not the company has complied with the Code and, if not, to give reasons for any non-compliance. ${ }^{61}$ Since 2006 , the EU also has a 'comply or explain' provision to promote better corporate governance. A Directive requires listed companies to include a corporate governance statement in its annual report containing a

\footnotetext{
${ }^{54}$ California Transparency in Supply Chains Act of 2010, <info.sen.ca.gov/pub/09-10/bill/sen/sb_06510700/sb_657_bill_20100930_chaptered.html>.

${ }^{55}$ Regulation (EU) No 995/2010 of the European Parliament and of the Council of 20 October 2010 laying down the obligations of operators who place timber and timber products on the market, Official Journal of the European Union, 12 November 2010.

${ }^{56}$ In addition, the EU showed that "[ $\left.\mathrm{t}\right]$ he European Commission has recently completed a guide on the social considerations in public procurement, launched an ongoing public consultation on non-financial reporting and expects to put forward a new policy initiative on corporate social responsibility later this year, including proposals on how to implement further the UN Framework". EU Comments, supra note 25.

${ }^{57}$ Directive 2003/51/EC on the annual and consolidated accounts of certain types of companies, banks and other financial institutions and insurance undertakings.

${ }^{58}$ For submissions received during the public consultation period, and other documents see <ec.europa.eu/enterprise/policies/sustainable-business/corporate-social-responsibility/reportingdisclosure/index_en.htm>.

${ }^{59}$ V. Wensen et al., The State of Play in Sustainability Reporting in the European Union, European Union, 2011, p. 5.

${ }^{60}$ As a definition, the OECD writes that "[c]orporate governance involves a set of relationships between a company's management, its board, its shareholders and other stakeholders. Corporate governance also provides the structure through which the objectives of the company are set, and the means of attaining those objectives and monitoring performance are determined.” OECD Principles of Corporate Governance, OECD, 2004, Preface, p. 11. ${ }^{61}$ Para. 12.43A of the London Stock Exchange Listing Rules.
} 
reference to the corporate governance code to which the company subscribes and to the extent to which the company departs from this code an explanation as to the reasons for not applying it. ${ }^{62}$

The regulations above exhibit mandatory reporting coupled to an authoritative and detailed code, or 'soft law' instrument. Simpler versions that, at least for the time being, lose the soft law component exist in the US. There, the Sarbanes Oxley Act (2002) requires, among others, that companies either adopt and then disclose a 'code of ethics' addressing compliance with law and ethical conduct by key corporate officers, or explain publicly why the company has not adopted such a code. ${ }^{63}$ As Catá Backer explains, "the object was not to impose ethics codes but to create a legal framework within which stakeholders could negotiate the extent and terms of such codes". ${ }^{64}$ There is an evolutionary component built in this regulatory strategy as there is always the possibility to add later the authoritative and more detailed soft law standards.

To remain in the corporate governance area, some states have adopted regulations asking institutional investors themselves, rather than the companies they invest in, to be more transparent on their investment decisions. Back in 1999, the CSR community welcomed the UK's Occupational Pension Schemes Regulations which asked pension funds to state "the extent (if at all) to which social, environmental or ethical considerations are taken into account in the selection, retention and realisation of investments". ${ }^{65}$ This example was quickly replicated in Australia, with more detail required from a broader range of institutional investors. ${ }^{66}$ These laws clearly legitimise a discussion of CSR among corporate governance stakeholders. But they also remove explicit prohibitions or implicit understandings prompting investment managers to ignore CSR considerations. Indeed a study commissioned by Ruggie described how some investment funds in Australia and the US are not allowed to take CSR into account. ${ }^{67}$ Such apparently 'mild' legal provisions thus serve a useful purpose, and Ruggie noted in relation to

\footnotetext{
${ }^{62}$ Amendments to Directive 78/660/EEC, Article 46a, Directive 2006/46/EC amending Council Directives $78 / 660 / \mathrm{EEC}$ on the annual accounts of certain types of companies, 83/349/EEC on consolidated accounts, 86/635/EEC on the annual accounts and consolidated accounts of banks and other financial institutions and 91/674/EEC on the annual accounts and consolidated accounts of insurance undertakings, Official Journal of the European Union, 16 August 2006. See also European Commission, The EU corporate governance framework, Green Paper, COM(2011) 164 final, 2011, p. 2.

${ }^{63}$ Sarbanes-Oxley Act, Section 406 (a)(b) 'Code of Ethics for Senior Financial Officers' in Title IV 'Enhanced Financial Disclosures'.

${ }^{64}$ L. Catá Backer, 'From Moral Obligation to International Law: Disclosure Systems, Markets and the Regulation of Multinational Corporations', 39 Georgetown Journal of International Law (2008) p. 138.

${ }^{65}$ Occupational Pension Schemes (Investment, and Assignment, Forfeiture, Bankruptcy etc.) Amendment Regulations 1999, Article 11A. The effects of the law can be gleaned from the biennial survey on responsible investment practices of UK corporate pension funds that the USKIF publishes. See UK Sustainable Investment and Finance, Responsible Business: Sustainable Pension, 2011, <www.uksif.org/cmsfiles/281411/25_Aug_UKSIF_Pensions_Report_2011.pdf>.

${ }^{66}$ For how the Australian regime has delivered transparency in the last decade, especially the effectiveness of the guidance provided by the Commission and the compliance response from the industry, see E. Banasik, M. Barut and L. Kloot, 'Socially Responsible Investment: Labour Standards and Environmental, Social and Ethical Disclosures within the SRI Industry', Australian Accounting Review, No. 55 Vol. 20 Issue 4, 2010.

${ }^{67}$ For example, and SRSG report noted that "[i]n the U.S. the Department of Labor has guidelines which formalize the ambit of a fund manager's discretion. Under these guidelines, the managers of employee benefit plans may 'never subordinate the economic interests of the plan to unrelated objectives, and may not select investments on the basis of any factor outside the economic interest of the plan." Human rights and corporate law: trends and observations from a crossnational study conducted by the Special Representative, Addendum 2 to the Report, A/HRC/17/31/Add.2, 2011, para. 175 (hereinafter 'Human rights and corporate law').
} 
the UK law that "the government recently confirmed that pension fund trustees are not prohibited from considering social, environmental and ethical issues in their investment decisions, provided they act in the fund's best interests. This guidance stemmed from calls to reform legislation governing pension funds to explicitly allow, and in some cases require, consideration of social and environmental issues, including human rights."68

There should be no mistake when assessing the flurry of corporate governance regulations relevant to CSR: these regulations aim to enlarge managers' margin of manoeuvre and guide them to a better identification of new types of risks. The purpose though remains the same: high return on investment and corporate profitability. Clarifications in company law, as done extensively in the UK in 2006, are meant to dispel misunderstandings and eliminate express prohibitions for taking CSR into account, but clearly they are not meant to have human rights trump profitability. The UK Companies Act clarifies what the duty of care that business directors have under company law entails:

A director of a company must act in the way he considers, in good faith, would be most likely to promote the success of the company for the benefit of its members as a whole, and in doing so have regard (amongst other matters) to -

(a) the likely consequences of any decision in the long term,

(b) the interests of the company's employees,

(c) the need to foster the company's business relationships with suppliers, customers and others,

(d) the impact of the company's operations on the community and the environment,

(e) the desirability of the company maintaining a reputation for high standards of business conduct ... ${ }^{69}$

To promote the respect of this duty, the law requires a report ('the business review') with the purpose "to inform members of the company and help them assess how the directors have performed their duty under section 172 (duty to promote the success of the company)". ${ }^{70}$

When company laws in other jurisdictions do not refer explicitly to the interests of the shareholders and instead use formulations such as the 'best interests of the company', an opening seems to appear to play up the interests of stakeholders. "One could interpret 'the company' as a reference to a social institution, creating a duty to act in the interests of all stakeholders instead of just shareholders alone", an International Commission of Jurists study remarked. ${ }^{71}$ But it rightly warned that "[e]nthusiasm for these possibilities should remain cautious ... More inclusive fiduciary duties do not respond to the danger that victim's interests will be recognised, but outweighed. Responding to this means imposing specific legal duties to respect certain interests." 72

Ruggie commissioned a study investigating the obstacles as well as the potential of company laws in promoting CSR. ${ }^{73}$ His correct starting point was that "[c] orporate and securities law directly shapes what companies do and how they do it. Yet its implications for human rights

${ }^{68}$ Ibid., para. 176.

${ }^{69}$ Article 172(1), Companies Act 2006

${ }^{70}$ Ibid., Article 417(2).

${ }^{71}$ Access to Justice: Human Rights Abuses Involving Corporations, South Africa, International Commission of Jurists, 2010, p. 9. <www.icj.org/dwn/database/SouthAfrica-ElecDist.pdf>.

${ }_{73}^{72}$ Ibid., p. 10. (emphasis added).

${ }^{73}$ Human rights and corporate law, supra note 67. 
remain poorly understood." ${ }^{, 74}$ For this reason, there are calls to rewrite the company laws on the managerial duty of care in order to promote stakeholder interests, including the protection of human rights. Ruggie's study of 39 jurisdictions found in this respect that " $[\mathrm{m}]$ ost surveyed jurisdictions do not expressly require any recognition of a duty to society or respect for human rights as a condition of incorporation or listing". 75 The problem is that even if they would do it, such duties of care are hardly legally enforceable in courts. ${ }^{76}$ Stevelman wrote about the duty of care owed by corporate managers and directors to the company and shareholders: "[A]s an enforceable legal standard, as opposed to an essentially hortatory, normative one, the duty of care is essentially moribund. Charter exculpation provisions, corporate indemnification, and corporate-funded directors' and officers' insurance have generally limited, or eliminated, the potential for holding these managers personally liable in suits alleging breach of due care.",77

The solution would be to say that companies owe the society a duty of care, but this is a matter of general tort law offering compensation for harm done, or otherwise commonly done in other specialised legal fields such as environmental law or labour law that protect specific interests. But such duty of care would not be a duty of care under company law which deals basically with duties that managers owe to the corporation for the purposes of profit-making. Therefore revisions of corporate duties have to be performed in other bodies of law if one counts on judicial enforcement and on managers not having the discretion (and responsibility) to balance corporate success and stakeholder protection. One such body of law is tort law, as illustrated with litigation under the US Alien Tort Claims Act and British tort law in the next section.

Ruggie values these developments in corporate governance and places them in the context of 'corporate culture'. He elaborated on three types of laws able to foster 'rights-respecting corporate cultures': reporting requirements, directors' duties, and legal provisions specifically recognising the concept of 'corporate culture' such as the US Sentencing Guidelines. ${ }^{78}$ He deems that "[g]overnments are uniquely placed to foster corporate cultures in which respecting rights is an integral part of doing business ... Sustainability reporting can enable stakeholders to compare rights-related performance.",79

In conclusion, recent developments in corporate governance hold at least two implications for CSR. First, they present a complex regulatory approach to shaping corporate behaviour. The limits of judicial coercion prompted the corporate governance regime to try to shape behaviour through an interesting mix of authoritative codes (soft law) and legally-binding disclosure requirements working in tandem to put the spotlight on sub-par, careless managerial practices and empower beneficiaries (primarily shareholders, but also indirectly some other stakeholders). This approach in national corporate governance parallels nicely Ruggie's understanding and attempt to strengthen a global governance regime that is not entirely dependent on state action,

\footnotetext{
${ }^{74}$ Ibid., para. 10.

${ }^{75}$ Ibid., para. 50.

${ }^{76}$ Mares, supra note 45, ch. 2.

${ }^{77}$ F. Stevelman, 'Globalization and Corporate Social Responsibility: Challenges for the Academy, Future Lawyers, and Corporate Law', New York Law School Law Review, 2008/2009, p. 837 (reference omitted).

${ }^{78}$ Business and Human Rights: Further steps toward the operationalization of the 'protect, respect and remedy' framework, A/HRC/14/27, 2010, paras. 36-43 (hereinafter 'Further steps').

${ }^{79}$ Protect, Respect and Remedy, supra note 14, paras. 29-30.
} 
hard law and judicial enforcement. ${ }^{80}$ In both corporate governance and CSR there is a strong emphasis on transparency and soft law. The important difference between the two regimes lies, of course, in the self-help capacities of the beneficiaries: the shareholders have a legallysanctioned power over the management and access to the huge leverage of financial markets while human rights holders lack this type of power and markets working for them to keep business executives in check.

The second implication is that corporate governance and CSR travel on the same road, but only part of the way. Recent clarifications of managerial duties of care and legal requirements for disclosure of non-financial information are two engines slowly aligning corporate governance with CSR objectives. And they serve to prevent corporate governance from severely shortcutting CSR efforts, as shown above. But corporate governance has inherent limitations given the fundamental orientation towards interests of the company and/or shareholders and the wealthcreating function of the enterprise. The boost from corporate governance is notable but needs to be maintained through other engines if the rocket is to keep flying. Laws outside of the corporate governance regime, contracts and other non-legalistic rationalities must play their part to deliver accountability towards stakeholders.

\subsubsection{Tort}

The Alien Tort Claims Act (ATCA) in the US offers the main litigation arena against MNEs ${ }^{81}$ of interest to CSR due to its peculiar reference to international law. ${ }^{82}$ Ruggie has followed it closely and borrowed the legal definition of complicity from the ATCA courts' rulings on 'aiding and abetting' ${ }^{83}$ He openly spoke against a recent decision of a US court that imposed an impossibly high 'knowledge standard' for companies to be held liable as accomplices. ${ }^{84}$ While no plaintiff has so far succeeded on the merits in an ATCA court, a few settlements have been reached and some procedural hurdles hindering access to justice have been cleared. ${ }^{85}$ Not all is going uphill for the ATCA plaintiffs as exemplified by two notable setbacks taking place in 2009 and $2010 .{ }^{86}$

\footnotetext{
${ }^{80}$ The EU endorsed Ruggie's orientation and suggested that "[t]he so-called 'smart mix' of regulatory and voluntary policy instruments is a pragmatic approach which is already followed to a greater or lesser extent in many States.” EU comments, supra note 25.

${ }^{81}$ For a comprehensive source of materials and news on corporate human rights litigation, see the Corporate Legal Accountability Portal, <www.business-humanrights.org/LegalPortal/Home>

82 "The district courts shall have original jurisdiction of any civil action by an alien for a tort only, committed in violation of the law of nations or a treaty of the United States." Alien Tort Claims Act, 28 USC 1350, 1789. For more on the ATCA, see M. Gottridge et al., The Alien Tort Statute: An Introduction And Current Topics, Litigation and Administrative Practice Course Handbook Series, Practising Law Institute, 2010.

${ }^{83}$ Protect, Respect and Remedy, supra note 14, para. 74.

${ }^{84}$ Brief of Amicus Curiae International Law Scholars, Presbyterian Church of Sudan v. Talisman Energy, Inc., on petition for a writ of certiorari from the Supreme Court to the US Court of Appeals for the Second Circuit, 2010 WL 1787371 (2010), p. 24.

${ }^{85}$ For a list of cases, see Center for Constitutional Rights et al., Universal Periodic Review (United States of America), Stakeholder Submission on United States Obligations to Respect, Protect and Remedy Human Rights in the Context of Business Activities, 19 April 2010, <www.earthrights.org/sites/default/files/documents/escrnet-uprapril-19-2010.pdf>.

${ }^{86}$ For a detailed discussion of recent developments under ATCA see the chapter by Knox in this volume.
} 
Overseas plaintiffs have approached British courts to hold corporations accountable by using general principles of negligence law. The pioneering work ${ }^{87}$ done by the law firm Leigh Day \& Co and Richard Meeran has resulted in recent high profile settlements with companies such as Trafigura for dumping toxic waste in the Ivory Coast (settled in 2009), Monterrico Metals for its involvement in repressive actions in Peru (settled in 2011) and Shell for pollution in Nigeria (Shell accepted responsibility in 2011). ${ }^{88}$ A court case started in 2011 pits Columbian farmers as plaintiffs against BP for its alleged negligence that resulted in an oil spill that poisoned water, destroyed crops and killed livestock. ${ }^{89}$

Host country courts have recently surprised transnational corporations (TNCs) with high awards. An Ecuadorian court ruled in 2011 that Chevron has to pay USD 18 billion for Texaco's pollution decades ago. ${ }^{90}$

Ruggie has consistently emphasised the importance of judicial mechanisms throughout his reports. His elaborations of Pillar 3 on access to remedies have highlighted the legal and practical barriers that plaintiffs face, ${ }^{91}$ and called upon home states to keep their courts open to plaintiffs from abroad. In this respect he recommended that "States should strengthen judicial capacity to hear complaints and enforce remedies against all corporations operating or based in their territory, while also protecting against frivolous claims. States should address obstacles to access to justice, including for foreign plaintiffs - especially where alleged abuses reach the level of widespread and systematic human rights violations." ${ }^{, 92}$ In his 2009 he detailed:

\begin{abstract}
Where the company is a subsidiary of an overseas parent, additional factors can compound these barriers. The parent company may use its own leverage with the host Government or mobilize the home Government and international financial institutions. The alternative of filing a suit in the parent company's home State for the subsidiary's actions, or for the parent's own acts or omissions, can raise jurisdictional questions about whether it is the appropriate forum, and may trigger policy objections by both home and host State Governments. Moreover, the standards expected of parent companies with regard to subsidiaries may be unclear or untested in national law. Such transnational claims also raise their own evidentiary, representational, and financial difficulties. ${ }^{93}$
\end{abstract}

\title{
7.1.4. Contract
}

Ruggie has emphasised the importance of commercial contracts incorporating CSR provisions. The economic leverage of governmental agencies, banks and large companies is considerable.

The issue of public procurement is a key contractual means through which states, as economic actors, can influence corporate behaviour. 'Socially responsible public procurement' has trailed developments in responsible supply chain management with which large private companies have

\footnotetext{
${ }^{87}$ Lubbe v. Cape Plc [2000] 1 WLR 1545, 2 Lloyd's L. Rep 383; Connelly v. RTZ [1996] 3 WLR 373; Sithole \& Ors v. Thor Chemicals Holdings Ltd \& Anor TLR, 15 February 1999.

${ }^{88}$ For a detailed account of how a transnational liability case is litigated, see J. McCulloch, 'Beating the odds: The quest for justice by South African asbestos mining communities', Review of African Political Economy (2005).

${ }^{89}$ D.Taylor, 'BP oil spill: Colombian farmers sue for negligence, The Guardian, 11 January 2011.

${ }^{90}$ For documents on this long-running case, see <chevrontoxico.com>.

${ }^{91}$ Guiding Principles, supra note 1, Principle No. 26.

${ }^{92}$ Protect, Respect and Remedy, supra note 14, para. 91.

93 Towards operationalizing, supra note 11, para. 95.
} 
experimented since the mid-1990s. ${ }^{94}$ Now governments are more explicit on their role in "setting an example and influencing the market-place", as the European Commission recently stated. ${ }^{95}$ In the United States, all contractors doing significant business with the Federal Government must certify that they have compliance programmes rooted in ethical and legally compliant cultures, based on those required in the Sentencing Guidelines. ${ }^{96}$ Also in the US, an Executive Order from 1999 targets goods produced by forced child labour. Accordingly, public federal procurement shall include special provisions in contracts to the effect that the contractor has to certify that a good faith effort was made to determine whether forced or indentured child labour was used, and to cooperate in providing access to the contractor's records, documents, persons or premises. The sanctions on contractors are termination of contract, debarring from eligibility for future contracts and inclusion on a List of Parties Excluded from Federal Procurement. ${ }^{97}$

Contractual provisions on CSR are also increasingly incorporated in the financing and guarantees states offer to companies. Ruggie noted that the law in the US now directs the Overseas Private Investment Corporation to issue "a comprehensive set of environmental, transparency and internationally recognized worker rights and human rights guidelines with requirements binding on the Corporation and its investors". ${ }^{98}$ Likeminded regulations are targeting national export credit agencies (ECAs) in the EU through new transparency requirements. Recently, EU countries agreed that they will submit yearly reports explaining how effectively their ECAs assess the environmental and human rights risks of the commercial ventures they back. ${ }^{99}$ At the international level, the IFC has for years had Performance Standards; these have been updated recently and make direct reference to Ruggie's due diligence recommendations. ${ }^{100}$

Contracts between private companies have long been seen as a key lever in the CSR area. For example, the discussions on supply chain management are premised on the leverage that influential companies have over their suppliers and distributors, leverage that can be formalised in contractual provisions. ${ }^{101}$ CSR provisions have found their way into contracts through which

\footnotetext{
${ }^{94}$ See C. McCrudden, 'Corporate Social Responsibility and Public Procurement', in D. McBarnet, A. Voiculescu, T. Campbell (eds.), The New Corporate Accountability: Corporate Social Responsibility and the Law (Cambridge University Press, 2007)

${ }^{95}$ European Commission, Buying Social - A Guide to Taking Account of Social Considerations in Public Procurement, 2010, p. 5.

${ }^{96}$ United States Federal Register, Vol. 73, No. 219, 12 November 2008 (referred to in Further steps, supra note 78, para. 31)

${ }^{97}$ Executive Order 13126 Prohibition of Acquisition of Products Produced by Forced or Indentured Child Labor (12 June 1999). For the effects of this regulation, see R. Woodard, Sourcing: US labour 'blacklisting' a wake-up call to India?, 20 July 2010, <www.just-style.com/analysis/us-labour-blacklisting-a-wake-up-call-toindia id108351.aspx>; 'US Sees Big Drop in Child Labour Use by Indian Carpet-Makers', Sify News, 20 July 2010 , <sify.com/news/us-sees-big-drop-in-child-labour-use-by-indian-carpet-makers-news-internationalkhunacfgihg.html>.

${ }^{98}$ Further steps, supra note 78 , para. 29.

${ }^{99}$ Amnesty International, ECA-Watch and Eurodad, 'Giving human rights credit: EU countries agree to toughen export loan scrutiny', Press release, 29 June 2011.

${ }^{100}$ Its general Performance Standard reads: "Business should respect human rights, which means to avoid infringing on the human rights of others and address adverse human rights impacts business may cause or contribute to." IFC, Assessment and Management of Environmental and Social Risks and Impacts, Performance Standard 1, 2012, para. 3.

${ }^{101}$ M. P. Vandenbergh, 'The New Wal-Mart Effect: The Role of Private Contracting in Global Governance', 54 UCLA Law Review (April 2007) p. 913.
} 
one party communicates its codes of conduct and expectations, outlines due diligence measures and provides that non-compliance can be a ground for termination of contract. ${ }^{102}$ Outside the area of supply chain responsibility there are interesting developments taking place. For example, regarding access to medicines, a pharmaceutical company expanded access to medicines by signing an immunity-from-suit agreement with a generic company enabling the latter to manufacture and sell the medicine in sub-Saharan Africa and India. ${ }^{103}$ Such an approach goes a long way from the practices a decade ago of pharma companies protecting fiercely their HIV/AIDS medicine patents in developing countries. ${ }^{104}$

\subsubsection{Soft Law}

At the international level, there have been important standard setting efforts through which states have crystallised their expectations regarding responsible business behaviour. Major international governmental organisations took the lead in the 1970s and recently they sought to bring into line their human rights provisions with Ruggie's due diligence recommendations. It can be said that a battery of soft law currently exists. The OECD has revised in 2011 its Guidelines for MNEs originally adopted in $1976,{ }^{105}$ and additionally it adopted due diligence recommendations pertinent to the trade in conflict minerals, also in $2011 .^{106}$ The International Labour Organization (ILO) still has its 1977 Declaration for MNEs outlining relevant labour rights, a document that is periodically updated. The IFC has updated its Performance Standards for project finance in $2011 .{ }^{107}$ In late 2010 the ISO released a detailed guidance on social responsibility. ${ }^{108}$ The European Commission has applauded Ruggie's Framework and will reference it in its next CSR policy paper. ${ }^{109}$ Regarding sustainability reporting, the Global Reporting Initiative is working on its fourth generation of Reporting Guidelines to be released in 2013. ${ }^{110}$ And now the HRC has sanctioned Ruggie's Framework and Guiding Principles. Numerous other multistakeholder initiatives exist in diverse industries such as extractives, labour intensive industries, information technology, agriculture and many others. ${ }^{111}$

\footnotetext{
${ }^{102}$ For an example, see GlaxoSmithKline, The GSK standard contract clause for Ethical Standards and Human Rights, 2011, <www.gsk.com/responsibility/cr-report-2010/supply-chain/supplier-standards/human-rightsclause.htm> (accessed 7 September 2011). For a discussion, see B. Martin, Can transnational corporations legally apply conditions to companies that supply them with contract and agency labour?, Report for International Federation of Chemical, Energy, Mine and General Workers' Unions (ICEM), 2007, <www.publicworld.org/files/icemlegal.pdf>.

${ }^{103}$ Bristol-Myers Squibb Signs New Agreement to Expand Access to Reyataz(R) (atazanavir sulfate) in sub-Saharan Africa and India, Bristol-Myers Squibb Press Release, 28 June 2011.

${ }^{104}$ M. Heywood, 'South Africa's Treatment Action Campaign: Combining Law and Social Mobilization to Realize the Right to Health', 1:1 Journal of Human Rights Practice (March 2009) pp. 14-36.

105 OECD, Guidelines for Multinational Enterprises, 2011.

${ }^{106}$ OECD, Due Diligence Guidance for Responsible Supply Chains of Minerals from Conflict-Affected and HighRisk Areas, OECD Publishing, 2011.

${ }^{107}$ There are eight Performance Standards, effective from 1 January 2012.

${ }^{108}$ International Organisation for Standardisation, Guidance on Social Responsibility, ISO 26000, 2010.

${ }^{109}$ See EU Comments, supra note 25. Already in its 2006 White paper on CSR, the Commission wrote that it was following the progress of the SRSG. European Commission, Implementing the Partnership for Growth and Jobs: Making Europe a Pole of Excellence on Corporate Social Responsibility, COM(2006) 136 final (Brussels, 2006), p. 6, <www.coess.org/documents/com_2006_0136.pdf>.

$110<$ www.globalreporting.org>.

${ }^{111}$ See R. Mares (ed.), Business and Human Rights - A Compilation of Documents (Martinus Nijhoff Publishers, 2004).
} 
Ruggie wrote in relation to soft law:

[T]he standard-setting role of soft law remains as important as ever to crystallize emerging norms in the international community. The increased focus on accountability in some intergovernmental arrangements, coupled with the innovations in soft law mechanisms that involve corporations directly in regulatory rulemaking and implementation, suggests increased state and corporate acknowledgment of evolving social expectations and a recognition of the need to exercise shared responsibility. ${ }^{112}$

\subsection{Ruggie's Legal Questions and Answers}

These legal developments have been duly noted in the SRSG reports. Throughout his mandate Ruggie sought to answer many questions of immediate relevance to lawyers.

Does international law impose obligations on corporations, that is, private actors? He concluded that "the treaties do not address direct corporate legal responsibilities explicitly, while the treaty bodies' commentaries on the subject are ambiguous ... In conclusion, it does not seem that the international human rights instruments discussed here currently impose direct legal responsibilities on corporations." 113 Is there a principled obstacle for international law doing that? He wrote that "[n]othing prevents states from imposing international legal responsibilities for human rights directly on corporations". ${ }^{114}$ Were the Draft Norms a restatement of international law as its authors claimed? Ruggie understood that "restatements 'reflect the law as it presently stands or might plausibly be stated by a court.' The idea that the Norms project amounted to no more than a 'restatement' of legal principles was contested by business and also questioned by academic observers."

What is the relation of the Guiding Principles with international law? Ruggie thought that "[t]he Guiding Principles' normative contribution lies not in the creation of new international law obligations but in elaborating the implications of existing standards and practices for States and businesses; integrating them within a single, logically coherent and comprehensive template; and identifying where the current regime falls short and how it should be improved". ${ }^{116}$ Further, "[n]othing in these Guiding Principles should be read as creating new international law obligations, or as limiting or undermining any legal obligations a State may have undertaken or be subject to under international law with regard to human rights". ${ }^{117}$

What is expected from companies where domestic law conflicts with international standards? Ruggie deemed that "[o]ne of the toughest dilemmas companies face is where national law significantly contradicts and does not offer the same level of protection as international human rights standards. National authorities may demand compliance with the law, while other stakeholders may advocate adherence to international standards, as might the company itself, for

\footnotetext{
${ }^{112}$ Business and Human Rights: Mapping International Standards of Responsibility and Accountability for Corporate Acts, A/HRC/4/035, 2007, para. 62 (hereinafter 'Mapping Standards').

113 Ibid., paras. 41 and 44.

${ }^{114}$ Ibid., para. 36.

${ }^{115}$ Evolving Agenda, supra note 37, p. 827 (references omitted).

${ }^{116}$ Guiding Principles, supra note 1, para. 14.

${ }^{117}$ Ibid., page 6.
} 
reasons of principle or simple consistency of policy." ${ }^{118}$ He recognised that such situations leave companies caught in the middle - in regard to for example freedom of association, gender equality, freedom of expression and right to privacy - and they should seek to "find ways to honour the spirit of international standards without violating national law". 119

Does international law have a role in the emerging CSR regime? Ruggie decided that "international law has an important role to play in constructing a global regime to govern business and human rights. The effectiveness of its contributions will be maximized if it is embedded within, and deployed in support of, an overall strategy of increasing governance capacity in the face of enormously complex and ever-changing forces of globalization." ${ }^{120}$ In outlining his strategy of achieving social change, Ruggie addressed the key question coming from civil society: "[W]hy not start the treaty-making process now, while simultaneously taking shorter-term practical steps?"121 Is a general international treaty on CSR the better way forward at this moment in time?

There is one thing the report does not do: recommend that states negotiate an overarching treaty imposing binding standards on companies under international law. Treaties form the bedrock of the international human rights system. Specific elements of the business and human rights agenda may become candidates for successful international legal instruments. But it is my carefully considered view that negotiations on an overarching treaty now would be unlikely to get off the ground, and even if they did the outcome could well leave us worse off than we are today ... It is essential to strengthen the international human rights regime to bridge protection gaps in relation to business. But more readily achievable alternatives to the status quo exist, involving both mandatory and voluntary measures ... ${ }^{122}$

Can home states regulate their companies operating internationally? Ruggie thought that "home states are already legally permitted, if not necessarily willing, to take more extensive action to regulate overseas human rights harm by corporations based in them without arousing host state ire". ${ }^{123}$ Does the home state's responsibility to protect human rights extend extraterritorially? Ruggie concluded that

[t]he [UN] Committees have not expressly interpreted the treaties as requiring states to exercise extraterritorial jurisdiction over abuses committed abroad by corporations domiciled in their territory. But nor do they seem to regard the treaties as prohibiting such action, and in some situations they have encouraged it ... In general, international law permits a state to exercise extraterritorial jurisdiction provided there is a recognized basis: where the actor or victim is a national, where the acts have substantial adverse effects on the state, or where specific international crimes are involved. ${ }^{124}$

How does a host state's duty to protect human rights fit in Ruggie's vision? He wrote:

\footnotetext{
${ }^{118}$ Towards operationalizing, supra note 11, para. 66.

${ }^{119}$ Ibid., paras. 67-68.

${ }^{120}$ Evolving Agenda, supra note 37, p. 840.

121 J. G. Ruggie, 'Business and human rights - Treaty road not travelled', Ethical Corporation, May 2008 (hereinafter 'Treaty road not travelled').

${ }^{122}$ Ibid. Ruggie was more positive to an intergovernmental process of drafting a narrow international legal instrument dealing with gross human rights abuses, potentially amounting to the level of international crimes. Recommendations on Follow-Up to the Mandate, Mandate of the Special Representative of the Secretary-General (SRSG) on the Issue of Human Rights and Transnational Corporations and other Business Enterprises, 2011, <www.business-humanrights.org/media/documents/ruggie/ruggie-special-mandate-follow-up-11-feb-2011.pdf>.

${ }^{123}$ Treaty road not travelled, supra note 121.

${ }^{124}$ Evolving Agenda, supra note 37, pp. 829-830.
} 
[A]ny 'grand strategy' needs to strengthen and build out from the existing capacity of states and the states system to regulate and adjudicate harmful actions by corporations, not undermine it. Currently, at the domestic level some governments may be unable to take effective action on their own, whether or not the will to do so is present. And in the international arena states may compete for access to markets and investments, as a result of which collective action problems may restrict or impede their serving as the international community's 'public authority.' This observation drives the desire to impose direct obligations on corporations under international law. But doing so can itself have adverse effects on governance capacities, as we have seen - leaving aside the question of any such proposals' current political feasibility and legal enforceability. Therefore, it seems more promising in the first instance to expand the international regime horizontally, by seeking to further clarify and progressively codify the duties of states to protect human rights against corporate violations: individually, as host and home states, as well as collectively through the 'international cooperation' requirement of several UN human rights treaties. This will also establish greater clarity regarding corporate responsibility and accountability, and create a broader understanding among states about where the current regime cannot be expected to function as intended, and its vertical extension, therefore, is essential. International instruments may well have a significant role to play in this process, but as carefully crafted precision tools complementing and augmenting existing institutional capacities. ${ }^{125}$

What implications for the duty to protect follow from the state-business nexus exemplified by state-owned enterprises, ${ }^{126}$ privatisation of public services ${ }^{127}$ and public procurement ${ }^{128}$ ? What features of investment agreements and international arbitration are problematic from a human rights perspective? ${ }^{129}$

What legal obstacles and opportunities for CSR exist in various bodies of law? For example, do directors' duties under company laws allow, encourage or require directors and senior management to consider a company's social impacts, including on human rights? ${ }^{130}$ Are human rights risks 'material' for purposes of financial reporting regulations? ${ }^{131}$ Would following Ruggie's recommendation actually increase the danger of corporate liability with businesses incriminating themselves "by providing external parties with information they would not otherwise have had to use against the company"? ${ }^{132}$ Or on the contrary, does due diligence offer a defence to companies unwilling to improve their performance and human rights impacts? Ruggie noted:

Conducting due diligence enables companies to identify and prevent adverse human rights impacts. Doing so also should provide corporate boards with strong protection against mismanagement claims by shareholders. In Alien Tort Statute and similar suits, proof that the company took every reasonable step to avoid involvement in the alleged violation can only count in its favour. However, the Special Representative would not support proposals that conducting human rights due diligence, by itself, should automatically and fully absolve a company from Alien Tort Statute or similar liability. ${ }^{133}$

\footnotetext{
${ }^{125}$ Ibid., pp. 838-839 (references omitted).

${ }^{126}$ Guiding Principles, supra note 1, Principle 4.

${ }^{127}$ Ibid., Principle 5.

${ }^{128}$ Ibid., Principle 6.

129 Towards operationalizing, supra note 11, paras. 28-37. See also Principles for responsible contracts: integrating the management of human rights risks into State-investor contract negotiations: guidance for negotiators, Addendum 3 to the Report, A/HRC/17/31/Add.3, 2011.

${ }^{130}$ Further steps, supra note 78, paras. 39-41. See also Human rights and corporate law, supra note 67.

${ }^{131}$ Further steps, supra note 78, paras. 38 and 69-76.

${ }^{132}$ Towards operationalizing, supra note 11 , para. 80 .

${ }^{133}$ Further steps, supra note 78, para. 86.
} 
What procedural obstacles and other hindrances exist that prevent victims from accessing judicial remedies? ${ }^{134}$ What is the state of currently available remedies? In this respect, as he accounted for recent CSR and regulatory developments, Ruggie warned that "this patchwork of mechanisms remains incomplete and flawed. It must be improved in its parts and as a whole."135 What is the role of state-based, non-judicial mechanisms, like national human rights institutions (NHRIs)? ${ }^{136}$ Ruggie observed that "[n]on-State mechanisms may be linked to industry-based or multi-industry organizations; to multi-stakeholder initiatives ensuring member compliance with standards; to project financiers requiring certain standards of clients; or to particular companies or projects. Non-State mechanisms must not undermine the strengthening of State institutions, particularly judicial mechanisms, but can offer additional opportunities for recourse and redress." 137 Would a global ombudsman that could receive and handle complaints be a way forward? Ruggie indicated that

[s]uch a mechanism would need to provide ready access without becoming a first port of call; offer effective processes without undermining the development of national mechanisms; provide timely responses while likely being located far from participants; and furnish appropriate solutions while dealing with different sectors, cultures and political contexts. It would need to show some early successes if faith in its capacity were not quickly to be undermined. To perform these tasks any such function would need to be well-resourced. Careful consideration should go into whether these criteria actually can and would be met before moving in this direction. ${ }^{138}$

What is the danger of looking at CSR mainly through legal lenses? He wrote:

$[\mathrm{M}]$ any elements of an overall strategy lie beyond the legal sphere altogether. Consequently, the interplay between systems of legal compliance and the broader social dynamics that can contribute to positive change needs to be carefully calibrated. No less of a human rights authority than Amartya Sen warns against viewing rights primarily as 'proto legal commands' or 'laws in waiting.' Doing so, he argues, would unduly constrict - he actually uses the term 'incarcerate' - the social logics and processes other than law that drive the evolving public recognition of rights. The implication of Sen' [s] insight for the business and human rights agenda is that any successful regime needs to motivate, activate, and benefit from all of the moral, social, and economic rationales that can affect the behavior of corporations. This requires providing incentives as well as punishments, identifying opportunities as well as risks, and building social movements and political coalitions that involve representation from all relevant sectors of society, including business - much as has been occurring in the environmental field. ${ }^{139}$

\section{The Bigger Picture}

Ruggie took note of a multitude of legal developments. He also regarded the importance and limitations of corporate self-regulation and multistakeholder initiatives. There seems to be no arguing that at the end of the day coercion will need to be amassed from various sources to deal

\footnotetext{
${ }^{134}$ Protect, Respect and Remedy, supra note 14, para. 89. See also Towards operationalizing, supra note 11, paras. 93-98; Further steps, supra note 78, paras. 103-113. See also Ruggie's letter to UK on the issue of legal aid reform, <www.business-humanrights.org/media/documents/ruggie/ruggie-ltr-to-uk-justice-mininster-djanogly-16-may2011.pdf>.

${ }^{135}$ Protect, Respect and Remedy, supra note 14, para. 87.

${ }^{136}$ For an analysis of Ruggie's treatment of NHRIs, see the chapter by Brodie in this volume.

${ }^{137}$ Protect, Respect and Remedy, supra note 14, para. 86.

138 Ibid., para. 103.

${ }^{139}$ Evolving Agenda, supra note 37, pp. 839-840 (references omitted).
} 
with corporate laggards. Often gathered (and sometimes dismissed) under the catch phrase of 'voluntarism', non-legally binding standards - laid down by states, private actors or a combination of both - and their enforcement obtained from other sources than judicial coercion have an important role to play. From a governance perspective, the dichotomy binding/nonbinding is hardly productive for grasping the dynamics and evolution of norm-making processes in the CSR area. ${ }^{140}$ The question still is how we get sufficient coerciveness. Where states have failed - unable or unwilling - in their responsibility to establish a regulatory framework, can corporate voluntarism play a facilitating role in getting the states to act, to regulate? And in complex regulatory situations can voluntarism complement and work in combination with hard law ${ }^{141}$

\subsection{Role of Voluntarism in the Norm-making Process and in the Functioning of Governance Regimes}

The first aspect refers to the role of voluntarism in facilitating law-making and law enforcement. Ruggie mentioned briefly, on a number of occasions, that "[a]s companies internalize the responsibility to respect, they will increasingly support State efforts to bring laggards along" ${ }^{142}$ Elsewhere he noted:

A related criticism is that voluntary initiatives undermine the prospect for more robust regulations or other public sector roles. But this claim is premature at best. There is little chance of transnational firms becoming subject to legally binding regulations at the global level any time soon; the political will or even capacity simply is not there, and much of the corporate world would unite to fight it. In contrast, voluntary initiatives over time may build an interest among leading firms for a more level playing field vis-à-vis laggards, thereby realigning the political balance in the corporate sector. ${ }^{143}$

On another occasion Ruggie anticipated that
at the end of the day the accumulation of experience inevitably will lead to a desire for greater benchmarking, for moving from 'good' to 'best' practices and even formal codification, so that some of the 'soft law' products of voluntary initiatives are likely to become 'harder' law down the road. The advocates will include industry leaders to lock in their own first-mover advantages, or wanting a level playing field vis-à-vis laggards - as happened when several major energy companies lobbied the US Congress for some form of greenhouse-gas limits after President Bush rejected the Kyoto Protocol. Laggards have a harder time opposing standards based on actual achievement of their peers than ex ante standards. ${ }^{14}$

These however are quite lapidary and optimistic views. It would have been valuable, in order to cut through the voluntary-mandatory controversy, to have Ruggie explain in more detail this process, key dynamics, key interactions, how norms get institutionalised in the regulatory sphere and so on. Maybe this is a task for which the academia is better positioned to pursue than the

\footnotetext{
${ }^{140}$ See R. Mares, 'Global Corporate Social Responsibility, Human Rights, and the Law: An Interactive Regulatory Perspective on the Voluntary-Mandatory Dichotomy', 1:2 Transnational Legal Theory (2010) pp. 221-285.

${ }^{141}$ See the chapter by Melish and Meidinger in this volume discussing the 'New Governance' scholarship and the need for 'orchestration'.

${ }^{142}$ Further steps, supra note 78, para. 123 (emphasis added).

${ }^{143}$ J. G. Ruggie, 'Reconstituting the Global Public Domain - Issues, Actors, and Practices', 10:4 European Journal of International Relations (2004) p. 518 (emphasis added).

${ }^{144}$ Ruggie, supra note 48, pp. 251-252 (reference omitted).
} 
SRSG mandate was, but it would go a long way to address well-founded concerns of NGOs that voluntary approaches displace much needed regulation. For example, Vogel reviewed contributions from political science, law, sociology, management, business ethics and international and development studies in an effort to account for "scholarship that is relevant to understanding the emergence, structure, and impact of civil regulation, and its significance as a new and evolving dimension of global economic governance". ${ }^{145}$

Some insights could nevertheless be gathered from a seminar convened by the SRSG and summarised in a 2008 SRSG report. It addresses explicitly the relationship of multi-stakeholder initiatives (MSIs) to regulation:

Critics often portray MSIs and voluntary standards generally as providing alternatives to or even means of escaping binding regulation. For most MSIs, however, the regulatory interface is much more complex. Some seek eventual public policy integration as a way of achieving scale, bringing in smaller firms, producers of commodities and other unbranded products, and companies and Governments from emerging markets which do not have other incentives to join. For others, the whole point is to get Governments to implement regulation they already have on the books.

Participants predicted that MSIs would need to focus more explicitly on their relationships to regulation in the future, for a variety of reasons. First, many leadership companies actually prefer regulatory solutions in some areas, where 'level playing fields' are business-critical. Second, MSIs are proving to be interesting platforms for joint policy advocacy. And third, to the extent that MSIs begin to shift entire markets, they are more likely to come under scrutiny from regulators at the national and international levels on competition and trade policy grounds.

While participants agreed that different MSIs would necessarily have different 'end games', they also felt that MSIs share an opportunity to use their experience to feed into smart regulation in the areas in which they work. ${ }^{146}$

It might be the case that Vogel articulated a key insight regarding CSR: "The long-term effectiveness of private labor codes may well lie in public recognition of their limitations, leading them to be replaced or complemented by more effective national and international public regulations." ${ }^{\prime 147}$ Such an evolutionary perspective could capture an essential dynamic associated to $\mathrm{CSR}^{148}$

Rather than delve on the qualitative dynamics of a long and sinuous process, Ruggie seems at times content with quantitative references to the 'tipping point': “[A]s is true of all voluntary and many statutory - initiatives, determined laggards find ways to avoid scrutiny. This problem is not unique to human rights, nor is it unprecedented in history. But once a tipping point is reached, societies somehow manage to mitigate if not eliminate the problem. The trick is getting to the tipping point - a goal to which this mandate is dedicated." 149

\footnotetext{
145 D. Vogel, 'Private Global Business Regulation', 11 Annual Review of Political Science (2008) p. 262.

${ }^{146}$ Summary of five multi-stakeholder consultations, Addendum 1 to the Report, A/HRC/8/5/Add.1, 2008, pp. 257259.

${ }^{147}$ Vogel, supra note 145, pp. 274-275.

148 The chapter by Skadegaard Thorsen and Andreasen in this volume analyses the evolution of voluntary initiatives covering labour standards in supply chains.

${ }^{149}$ Mapping Standards, supra note 112, para. 81.
} 
A more promising angle that Ruggie employs to cover this aspect has to do with the 'scaling-up' of various existing initiatives. He took note of industry and company self-regulation, multistakeholder initiatives, public-private hybrids combining mandatory with voluntary measures, various regulatory measures to promote a corporate culture respectful of human rights, and the potential of corporate liability for international crimes in some national courts. Then he deemed that "[w]ithout in any manner disparaging these steps, our fundamental problem is that there are too few of them, none has reached a scale commensurate with the challenges at hand, there is little cross-learning, and they do not cohere as parts of a more systemic response with cumulative effects." 150

It is commendable that Ruggie made the cumulative process the supreme ambition of his mandate: ${ }^{151}$ it emphasises the need to scale-up and impresses a much needed evolutionary perspective. For Ruggie international law and national laws have a clear role to play in this cumulative process even though law does not hold the answer to everything when it comes to the responsibilities and roles of businesses. He cautioned states to "not assume that businesses invariably prefer, or benefit from, state inaction, and they should consider a smart mix of measures - national and international, mandatory and voluntary - to foster business respect for human rights". ${ }^{152}$ And he firmly affirmed that

markets work optimally only if they are embedded within rules, customs and institutions. Markets themselves require these to survive and thrive, while society needs them to manage the adverse effects of market dynamics and produce the public goods that markets undersupply. Indeed, history teaches us that markets pose the greatest risks - to society and business itself - when their scope and power far exceed the reach of the institutional underpinnings that allow them to function smoothly and ensure their political sustainability. ${ }^{153}$

While Ruggie felt the need for many qualifications in his treatment of the role of law - at what level (international or national), by who (host or home states), on what issue (overarching or specific CSR instrument) and at what time (now or later) - he was trenchant on the role of states. Not only did he dedicate a pillar of his Framework to this issue, but he wrote: "The role of states in relation to human rights is not only primary, but also critical ... [T] he repertoire of policy instruments available to [host and home] states to improve the human rights performance of firms is far greater than most states currently employ."154 Elsewhere he considered that

not all state structures as a whole appear to have internalised the full meaning of the state duty to protect, and its implications with regard to preventing and punishing abuses by nonstate actors, including business. Nor do states seem to be taking full advantage of the many legal and policy tools at their disposal to meet their treaty obligations. Insofar as the duty to the protect lies at the very foundation of the international human rights regime, this uncertainty gives rise to concern. ${ }^{155}$

In his academic treatment of the global public domain, Ruggie wrote that "[T]he effect of the new global public domain is not to replace states, but to embed systems of governance in broader global frameworks of social capacity and agency that did not previously exist". ${ }^{156}$ It is in this

\footnotetext{
${ }^{150}$ Protect, Respect and Remedy, supra note 14, para. 106.

${ }^{151}$ See the quotation referenced by supra note 1 .

${ }^{152}$ Human rights and corporate law, supra note 67, para. 206.

${ }^{153}$ Protect, Respect and Remedy, supra note 14, para. 2.

${ }^{154}$ Interim Report, supra note 27, para 79.

${ }^{155}$ Mapping Standards, supra note 112, para. 86.

${ }^{156}$ Ruggie, supra note 143, p. 519.
} 
respect that Ruggie simultaneously qualifies the role of law as merely one of the rationalities shaping behaviour and unequivocally affirms the role of states. The result is what Catá Backer referred to as a 'polycentric (multi-layered and intertwined) system of governance'. ${ }^{157}$ In his assessment of the SRSG's efforts at coordination, leverage and scaling-up, Catá Backer wrote:

\begin{abstract}
We move here from vague notions of corporate social responsibility applied in an ad hoc basis by individual corporate and state actors to the elaboration of a multi-level system of polycentric governance. The process from conception to elaboration has been complicated by the need to challenge the basis for conventional governance - one grounded in the idea of the singularity of the state. The SRSG has proposed a set of principles for the governance of economic actors operating within and beyond the state that is grounded on both public and private power. The coordination of these two sources of authority, and their development of systems of behavior control will be the great challenge for the emerging system of economic globalization in the coming decades. ${ }^{158}$
\end{abstract}

Thus Catá Backer concluded that "if there is no one silver bullet for the governance of the human rights obligations of business, then it will be necessary to produce a polycentric (multi-layered and intertwined) system of governance." 159 States have a key role to play in the functioning of this governance system, and have to strive for consistency with their obligations and interests in other legal domains where economic interests assert themselves powerfully. With his 'duty to protect' pillar Ruggie forcefully drew attention to unacceptable inconsistencies in state practice.

The struggle to eliminate such inconsistencies can be placed against Fischer-Lescano and Teubner's writings on the fragmentation of global law. He warned that "[1] egal fragmentation is merely an ephemeral reflection of a more fundamental, multidimensional fragmentation of global society itself"; that "[a]ny aspirations to a normative unity of global law are thus doomed from the outset. A meta-level at which conflicts might be solved is wholly elusive both in global law and in global society"; and finally that "[l] egal fragmentation cannot itself be combated. At the best, a weak normative compatibility of the fragments might be achieved. However, this is dependent upon the ability of conflicts law to establish a specific network logic, which can effect a loose coupling of colliding units.",160

Consistent with Ruggie's refusal to reduce the CSR discussion to a hierarchical, legalistic take, Teubner and Fischer-Lescano wrote eloquently about legal dynamics at the global level, especially about the plurality of law-making mechanisms, and the complex landscape featuring the legal centre, the legal periphery and the social environments of law:

\begin{abstract}
What, however, will take the place of hierarchy of legal norms? The center-periphery divide. While courts occupy the center of law, the periphery of the diverse autonomous legal regimes is populated by political, economic, religious etc. organizational or spontaneous, collective or individual subjects of law, which, at the very borders of law, establish themselves in close contact to autonomous social sectors. Once again, it is the fragmentation of global society that establishes the new schisms between the legal center, the legal periphery and the social environments of law. In the zones of contact between the legal periphery and
\end{abstract}

\footnotetext{
${ }^{157}$ L. Catá Backer, 'On the Evolution of the United Nations' "Protect-Respect-Remedy" Project: The State, the Corporation and Human Rights in a Global Governance Context', 9:1 Santa Clara Journal of International Law (2010) p. 126.

${ }^{158}$ Ibid., p. 156.

${ }^{159}$ Ibid., p. 126 (reference omitted).

${ }^{160}$ A. Fischer-Lescano and G. Teubner, 'Regime-Collisions: The Vain Search For Legal Unity In The Fragmentation Of Global Law’, 25 Michigan Journal of International Law (Summer 2004) p. 1004.
} 
autonomous social sectors, an arena for a plurality of law-making mechanisms is established: standardized contracts, agreements of professional associations, routines of formal organizations, technical and scientific standardization, normalizations of behavior, and informal consensus between NGOs, the media and social public spheres. By virtue of their independent secondary norms that differ fundamentally from those of national or international law, genuinely self-contained regimes can establish themselves in line with the following technical definition: A regime is a union of rules laying down particular rights, duties and powers and rules having to do with the administration of such rules, including in particular rules for reacting to breaches. When such a regime seeks precedence in regard to the general law, we have a 'self-contained regime,' a special case of lex specialis. ${ }^{161}$

Such writings generate a more nuanced understanding of the reach and operation of law when it comes to globalised business operations. Such treatments resonate with Ruggie's elaboration of 'new global public domain' defined as "an increasingly institutionalized transnational arena of discourse, contestation, and action concerning the production of global public goods, involving private as well as public actors. It does not by itself determine global governance outcomes any more than its counterpart does at the domestic level. But it introduces opportunities for and constraints upon both global and national governance that did not exist in the past." ${ }^{162}$

The governance regime for CSR will have to be mindful of the danger that some businesses will play the RtR strategically. Ruggie made the RtR operational through the idea of due diligence. However a focus on procedures, and process-oriented regulations, runs the well-known danger of decoupling or symbolic conformity as a strategic response. Decoupling or ceremonial conformity, a form of opportunism, implies that "organizations under pressure to adopt particular structures or procedures may opt to respond in a ceremonial manner, making changes in their formal structures to signal conformity but then buffering internal units, allowing them to operate independent of these pressures". ${ }^{163}$ Jamali further elaborated that decoupling "is more likely in loosely coupled organizational fields, characterized by ambiguity, uncertainty, multiple conflicting expectations, high transaction costs, limited regulatory commitment, and the absence of mechanisms to monitor compliance". ${ }^{164}$ These features are strikingly present in the business and human rights area. ${ }^{165}$

Institutional theory has for some time dealt with the diffusion of organisational practices. However, as Jamali writes, awareness has grown that "conformity may have been exaggerated and that there are important elements of variation in terms of degree of agency, choice, proactiveness and self-interest in responding to institutional pressures". ${ }^{166}$ From several contributions to this volume transpires uneasiness with the process orientation that Ruggie, through the due diligence component, has impressed on his corporate responsibility treatment. They would have preferred a different approach able to deliver accountability and ensure real change through, for example, more specific, detailed definitions of corporate responsibilities for

\footnotetext{
161 Ibid., pp. 1012-1013 (references omitted).

${ }^{162}$ Ruggie, supra note 143, p. 504.

${ }^{163}$ R. W. Scott, Institutions and Organizations: Ideas and Interests (Sage, Thousand Oaks, CA, 2008) p. 171.

${ }^{164}$ D. Jamali, 'MNCs and International Accountability Standards through an Institutional Lens: Evidence of Symbolic Conformity or Decoupling', 95 Journal of Business Ethics (2010) p. 625 (references omitted).

${ }^{165}$ For an example, see the chapter by Haines, Macdonald and Balaton-Chrimes in this volume documenting corporate strategies of resistance on tea plantations in India.

166 Jamali, supra note 164, p. 618 (references omitted).
} 
each right; ${ }^{167}$ a right of participation for civil society; ${ }^{168}$ and more radical changes in corporate decision-making structures. ${ }^{169}$ In brief, Parker and Howe charge that Ruggie "underestimates the capacity of business to neutralize, deradicalize, individualize and formalize critique". 170

When all is said and done, did Ruggie downplay the need for law? Was he in favour of keeping companies deregulated ${ }^{171}$ Will his work have facilitated or hindered the emergence of much needed stronger regulatory frameworks? The law has clearly been the great polariser in the Norms/Ruggie controversy. ${ }^{172}$ Two different visions of social change collided. Law as the preeminent and indispensable mechanism for social change versus law at the right time, in the right quantities and in the right combination with other factors. Law, especially international law, as the 'silver bullet' versus a belief in the non-existence of a silver bullet. For Ruggie "there is no single silver bullet solution to the very complex business and human rights challenges. Instead, all social actors - states, businesses, and civil society - must learn to do many things differently. But those things must cohere and generate an interactive dynamic of cumulative progress - and that is precisely what the Protect, Respect and Remedy framework is intended to help achieve." 173

The framing and mapping performed by the SRSG mandate are remarkable. Ruggie broadened the debate and eloquently wrote about the puzzle in front of the CSR movement:

[W] hat we needed to focus on were exactly these gaps between an increasingly integrated global economy and the fragmented political and regulatory systems and how to bridge those gaps, which involved states, it involved businesses, it involved other actors, it involved preventative measures, it involved remedial measures, it would involve law, it would involve voluntarism - it was just a much bigger puzzle that had to be put together. ${ }^{174}$

${ }^{167}$ See the chapter by Sullivan and Hachez in this volume.

${ }^{168}$ See the chapter Melish and Meidinger in this volume.

${ }^{169}$ See the chapter Parker and Howe in this volume.

${ }^{170}$ Ibid., p. ??

${ }^{171}$ Weissbrodt, the main author of the Draft Norms, wrote: "The Special Representative of the Secretary-General was supposed to develop standards, but has instead attempted to derail the standard-setting process and bow to the corporate refusal to accept any standards except voluntary codes." D. Weissbrodt, 'Keynote Address: International Standard-Setting on the Human Rights Responsibilities of Businesses', 26 Berkeley Journal of International Law (2008) p. 373, at p. 390.

172 Just refer to HRW's critical assessment of the HRC decision on Ruggie: "[T]he council endorsed the status quo: a world where companies are encouraged, but not obliged, to respect human rights ... Guidance isn't enough - we need a mechanism to scrutinize how companies and governments apply these principles." Human Rights Watch, Global Rules Needed, Not Just Guidance, 16 June 2011, <www.hrw.org/node/99908

UN Human Rights Council: Weak Stance on Business Standards>. See also FIAN arguing in favour of binding international and national regulation and asking the HRC to "avoid promoting ineffective mechanisms ... such as the UN Global Compact and the OECD Guidelines on MNCs have proved largely ineffective to address human rights abuses by TNCs. They have frustrated the hopes of victims to obtain remedy, wasted the resources of civil society organisations and have been misused by some corporations as public relations vehicles vis-à-vis public criticism and as cover up for their real human rights performance." FIAN, Statement to the Delegations on the Human Rights Council 2011, 17th Session, 2011, <www.fian.org/news/press-releases/CSOs-respond-to-ruggiesguiding-principles-regarding-human-rights-and-transnational-corporations/pdf $>$.

${ }^{173}$ J. G. Ruggie, 'Engaging Business: Addressing Respect for Human Rights', Keynote Address to the U.S. Council for International Business, U.S. Chamber of Commerce, International Organization of Employers, Atlanta, 25 February 2010, <www.reports-and-materials.org/Ruggie-keynote-address-in-Atlanta-25-Feb-2010.pdf>.

${ }^{174}$ J. Sherman, 'Business and human rights: joining the dots', Interview with Ruggie, International Bar Association, July 2010. 
Elsewhere Ruggie reverted to his famous concept of the 'embedded liberalism compromise' and considered that

private governance produces only partial solutions, and its own unfolding brings the public sector back in. It is difficult at this early stage to be more precise, and thus it is doubly imperative not to exaggerate either the virtues or the effects of these institutional developments ... [T] he skewed distribution of agential capacity between North and South is too pronounced, accountability problems too pervasive and the distributional consequences of these kinds of global governance instruments too poorly understood for us to believe that they reflect some new stable equilibrium. What we can say is that a fundamental recalibration is going on of the public-private sector balance, and it is occurring at the global level no less than the domestic. Haltingly and erratically, something akin of an embedded liberalism compromise is being pulled and pushed into the global arena, and the corporate connection is a key element in that process. $^{175}$

Ruggie comprehensively mapped voluntary initiatives as well as relevant bodies of law. With his governance outlook he discouraged a dichotomous understanding of voluntary and mandatory initiatives, and drew attention to their interactions in governance regimes. Hopefully, now that he is relieved from the constraints of his SRSG mandate, Ruggie will outline his understanding of how the CSR regime will slowly tighten the grip around laggards, a job for which political scientists are particularly well placed to explain. ${ }^{176} \mathrm{He}$ compellingly framed the issue as caused by a 'governance gap' and mapped the field comprehensively, but the dynamics of closing this gap need further analysis. Ruggie already hinted at this when he observed that

[t]he terrain is fraught with strategic manipulation and the potential for shirking. But it also opens the door to more firmly institutionalizing an emerging global public domain by bringing the public sector in ... Now we are slowly beginning to come full circle: business wants to channel some of the pressure [from civil society actors] it faces into the construction of at least minimally effective public sectors, including at the global level. This sets up the possibility of a very different political dynamic than existed as recently as the 1990 s. $^{177}$

Institutional theory approaches seem able to cut through the voluntary/mandatory debate and explain deinstitutionalisation, diffusion and reinstitutionalisation of norms, such as the due diligence norm. ${ }^{178}$ It seems that the CSR debate is now ripe to begin exploring complementarities and leave behind the voluntary/mandatory divisiveness: through his work Ruggie has placed the interaction law/voluntarism higher on the agenda. ${ }^{179}$ As Vogel wrote:

One key research question has to do with the relationship between civil regulation and public or state regulation. Civil regulations and state policies can interact in many ways. Private regulatory standards can function to avoid additional state regulations, to complement or better enforce state regulations, as a

\footnotetext{
${ }^{175}$ Ruggie, supra note 48, p. 253.

${ }^{176}$ Vogel noted that: “'Governance without government' has long been observed and theorized by political scientists [describing] a 'postmodern world of multiple and overlapping authorities: sovereign and nonsovereign, territorial and non-territorial'." Vogel, supra note 145, p. 263 (references omitted).

${ }^{177}$ Ruggie, supra note 48, p. 252.

${ }^{178}$ G. Mantilla, 'Emerging International Human Rights Norms for Transnational Corporations', 15 Global Governance (2009) pp. 279-298. R. Greenwood et al., 'Theorizing Change: The Role of Professional Associations in the Transformation of Institutionalized Fields', 45:1 Academy of Management Journal (2002) pp. 58-80.

${ }^{179}$ K. Webb (ed.), Voluntary Codes: Private Governance, the Public Interest and Innovation, 2004, <www2.carleton.ca/sppa/research/publications>, (especially ch. 5: K. Webb and A. Morrison, 'The Law and Voluntary Codes: Examining the "Tangled Web").
} 
precursor to more stringent state regulations, or as a substitute for state regulations. Under what conditions and how frequently has each outcome occurred? ${ }^{180}$

\subsection{Role of Home States in the CSR Governance Regime}

The home states where transnational companies are headquartered have a key role in the global CSR regime. Ruggie has emphasised this role but resisted calls to acknowledge that the state's duty to protect in Pillar 1 applies extraterritorially to benefit populations overseas. NGOs have criticised Ruggie's choice because it leaves it to home states' discretion, instead of being an imperative, to regulate their TNCs through national laws and contracts, and through state-to-state instruments such as investment and trade agreements. ${ }^{181}$

De Schutter argued in favour of an obligation on the home States of TNCs to provide a remedy for victims abroad, which could take the form either of parent-based extraterritorial regulation imposing a due diligence obligation on parent companies, or foreign direct liability imposing prescriptions directly on the foreign subsidiaries. The former alternative appears preferable, he thought. As to the status of such a state obligation, "[w] hile this would build on current developments in the international law of human rights, it would also go beyond them in obliging the home State to exercise a form of extraterritorial jurisdiction over the corporations which have its nationality for their operations overseas". ${ }^{182}$

In her thorough analysis of the state's obligation to protect, Hakimi noticed that extraterritorial obligations to protect have received little attention in the academic literature compared with the obligation to respect. ${ }^{183}$ Augenstein looked closely at the jurisprudence of the European Court of Human Rights and found few and rather isolated instances pointing towards states' obligation to regulate their companies regarding impacts abroad. ${ }^{184}$

Ruggie has dealt with the issue of extraterritoriality at length in his reports ${ }^{185}$ and organised seminars on this theme. In his 2008 report he concluded:

Experts disagree on whether international law requires home States to help prevent human rights abuses abroad by corporations based within their territory. There is greater consensus that those States are not prohibited from doing so where a recognized basis of jurisdiction exists, and the actions of the home State meet an overall reasonableness test, which includes non-intervention in the internal affairs of other States... Further refinements of the legal understanding of the State duty to protect by authoritative bodies at national and international levels are highly desirable. ${ }^{186}$

\footnotetext{
${ }^{180}$ Vogel, supra note 145, p. 275.

${ }^{181}$ For a detailed treatment see Kinley's discussion of three important avenues - trade, aid and corporate responsibility - that developed states have at their disposal to strengthen the protection of human rights in less developed countries. D. Kinley, Civilising Globalisation, Human Rights and the Global Economy (Cambridge University Press, 2009).

182 O. De Schutter, Extraterritorial Jurisdiction as a tool for improving the Human Rights Accountability of Transnational Corporations, Background paper to seminar in Brussels on 3-4 November 2006, pp. 51-52.

${ }^{183}$ Hakimi, supra note 18, p. 376.

${ }^{184}$ D. Augenstein, State Responsibilities To Regulate And Adjudicate Corporate Activities Under The European Convention On Human Rights, Submission to the SRSG on the issue of Human Rights and Business, April 2011.

${ }^{185}$ For example, Mapping Standards, supra note 112, paras 10-18.

${ }^{186}$ Protect, Respect and Remedy, supra note 14, paras. 19 and 21 (reference omitted).
} 
The 2010 report, while still not characterising the duty to protect as extending extraterritorially, explained:

\begin{abstract}
In the heated debates about extraterritoriality regarding business and human rights, a critical distinction between two very different phenomena is usually obscured. One is jurisdiction exercised directly in relation to actors or activities overseas, such as criminal regimes governing child sex tourism, which rely on the nationality of the perpetrator no matter where the offence occurs. The other is domestic measures that have extraterritorial implications; for example, requiring corporate parents to report on the company's overall human rights policy and impacts, including those of its overseas subsidiaries. The latter phenomenon relies on territory as the jurisdictional basis, even though it may have extraterritorial implications. ${ }^{187}$
\end{abstract}

\title{
8.3. Role of Financial Actors in the CSR Governance Regime
}

The last decade has witnessed increased attention to the responsibilities and roles of financial actors. The main focus has been on the more direct relationships involved in project finance through which banks support projects, usually infrastructure projects. Large institutional investors, such as pension funds, supposedly taking a longer term outlook on their investment than other more speculative investors, ${ }^{188}$ have also attracted attention and sometimes regulatory interventions, as discussed before. Among the international initiatives in this area are the UNbacked Principles for Responsible Investment Initiative for institutional investors (2006) ${ }^{189}$ and the Ecuador Principles for banks, basically applying the IFC performance standards (2003). ${ }^{190}$ The financial crisis of 2008 brought to the forefront the tremendous complexities that came to characterise financial markets' vehicles and operations. ${ }^{191}$ The CSR movement is yet to come to grip with such complexities.

The SRSG portfolio of reports cover export credit agencies, stock exchanges, financial products such as socially responsible investment (SRI) indices, financial regulations requiring transparency, company law and securities law aspects and so on. And, as highlighted previously, he wrote eloquently about markets: "The challenge we face is a big one: we are caught up in a fundamental institutional misalignment in the world between economic forces and actors on the one hand, and the ability of societies to adapt to the adverse consequences of the economic forces and to take full advantage of the opportunities of the economic forces on the other hand." ${ }^{192}$ Still Ruggie's treatment in this area is tentative in the meaning that he took note of key actors and CSR initiatives but fell short of a fuller understanding of the responsibilities of investors and financial institutions. Except for the case of project finance, where the direct relationship between the financier and the specific project is straightforward and resembling complicity, the talk seems to be more about roles rather than responsibilities of financial institutions. ${ }^{193}$

\footnotetext{
${ }^{187}$ Further steps, supra note 78, para. 48.

${ }^{188}$ J. P. Hawley and A. T. Williams, The Rise of Fiduciary Capitalism: How Institutional Investors Can Make Corporate America More Democratic (University of Pennsylvania Press, Philadelphia, 2000).

189 <www.unpri.org>.

$190<$ www.equator-principles.com>.

${ }^{191}$ See the chapter by Dowell-Jones and Kinley in this volume.

192 J. G. Ruggie, 'Introductory Remarks', in Corporate Responsibility for Human Rights: Concepts, Examples, Approaches, Summary Report (Berlin), 21 January 2010, <www.humanrights-

business.org/files/report_thats_right.pdf>.

${ }^{193}$ See the chapter by Sullivan and Hachez in this volume on the role of institutional investors in CSR.
} 
Ruggie does not frame the relationship between investors and the companies they invest in as one of complicity: their offering of capital to companies is not seen as assistance or contribution to the commission of harm. The financiers' responsibilities are not discussed in the same breath with value chain responsibility either, despite clear similarities. In this respect, Catá Backer observed that

\begin{abstract}
[t]here is something of a disjunction between the SRSG's discussion of supply chain obligations of corporations, and the discussion of the obligations financial institutions involved in the financing of corporate activity ... It seems odd to suggest that an industry with such a sophisticated approach to the monitoring and control of borrowers would be incapable of adding another layer of monitoring and review - that centered on human rights - to an already well established list of risk assessment protocols. Indeed, it would seem that banks are in a better position to monitor compliance form their borrowers than companies might be able to monitor the conduct of their down chain supply chain partners. ${ }^{194}$
\end{abstract}

The idea on which an investor's responsibility to act seems to build comes less from CSR's notions of complicity ${ }^{195}$ and more from corporate governance where the emphasis in the last 15 years has been on active shareholding, active ownership. ${ }^{196}$ The view here is that uniformed and passive investors allow corporate managers to employ risky approaches that can harm business prospects and societies alike. As noted previously in the corporate governance section, the thrust here is the success of the business in the long term which requires a proper identification and management of all types of risks, including the risk that careless handling of human rights will backfire on the company. Having to rationalise the protection of human rights in terms of a company's own success is of course inherently limited, as discussed in a previous section.

Given the numerous intermediary financial institutions entangled in a web of inscrutable financial relationships and dealings, the way forward for CSR seems to point to the idea of 'shared responsibility' and the need for multistakeholder governance initiatives as a way of discharging it. For example, Keenan and Ochoa argue in favour of a 'shared duty to protect', meaning that "states, private actors, and international institutions should share the duty to protect those rights that are violated in connection with business and financial activity". ${ }^{197}$ They "propose a fairly bright line: when states and investors knowingly engage with host states that are unable to protect their own citizens against harms that may be committed or facilitated by the investment, they undertake to share this duty with the host state. In short, arrangements that result in investors benefiting from the dysfunctional nature of host states should give rise to the investor's obligation to share in the duty to protect human rights."

\footnotetext{
${ }^{194}$ L. Catá Backer, 'The United Nations" "Protect-Respect-Remedy" Project: Operationalizing a Global Human Rights Based Framework for the Regulation of Transnational Corporations', Conference Paper, Symposium: Corporations and International Law, Santa Clara University, 12-13 March 2010, p. 181.

195 A. Clapham and S. Jerbi, 'Categories of Corporate Complicity in Human Rights Abuses', 24 Hastings Int'l \& Comp. L. Rev. 339 (2001). International Commission of Jurists, Final Report of the Expert Legal Panel on Corporate Complicity in International Crimes (2008).

196 The OECD deems that "[t]he corporate governance framework should protect and facilitate the exercise of shareholders' rights”. OECD Principles of Corporate Governance, supra note 60, Section II, p. 19 (emphasis added)

${ }^{197}$ P. J. Keenan and C. Ochoa, 'The Human Rights Potential of Sovereign Wealth Funds', 40 Georgetown Journal of International Law (Summer 2009) p. 1151, at p. 1158.

${ }^{198}$ Ibid., p. 1158 (references omitted).
} 
Ruggie himself considered that "soft law hybrids have made a singular contribution by acknowledging that for some purposes the most sensible solution is to base initiatives on the notion of 'shared responsibility from the start'." transcript reads, Ruggie observed that the notion of shared responsibility

recognizes that the challenges arising from globalization are structural in character, involving governance gaps and governance failures. Accordingly, they cannot be resolved by an individual liability model of responsibility alone but also need to be dealt with in their own right. This requires a model of strategically coherent distributed action focused on realigning the relationships among actors, including States, corporations and civil society. ${ }^{200}$

\subsection{Role of Core Companies in the CSR Governance Regime}

\subsubsection{Responsibility of Parent and Buyer Companies regarding their Affiliates' Operations}

Through his RtR, Ruggie has simplified diverse expectations of what companies should do by distilling a responsibility to 'do no harm'. From the inflation of verbs used by the Draft Norms ${ }^{201}$ Ruggie has retained just one: 'respect' human rights meaning 'do no harm', 'do not infringe on human rights'. And this RtR is applied to all business, including TNCs and other large companies. Such complex business groups and networks have blurred boundaries and operate lawfully in accordance with the principle of legal separation of entities. The OECD observed that "[m]ultinational enterprises, like their domestic counterparts, have evolved to encompass a broader range of business arrangements and organisational forms. Strategic alliances and closer relations with suppliers and contractors tend to blur the boundaries of the enterprise."202 Unfortunately, Ruggie's treatment of the RtR is affected in insidious ways.

Ruggie and other voices in CSR of course have not overlooked these two aspects. Thus Ruggie recognised that " $[\mathrm{t}]$ he worst alleged corporate-related human rights abuses typically have involved third parties connected to a company's operations, such as security forces or suppliers, with the company being accused of complicity in whatever act was committed by that third party. In a number of cases the allegations have included war crimes and crimes against humanity."203 Further Ruggie took note of the doctrine of limited liability and of arms-length market exchanges as he discussed network-based and hierarchical business structures. He acknowledged that " $[\mathrm{t}]$ ransnational corporate networks pose a regulatory challenge to the international legal system". ${ }^{204}$ This legal separation is no small obstacle as Catá Backer signalled: "As a matter of corporate law in virtually every jurisdiction, the essence of legal personality, and the autonomy of separately chartered corporations serve as the bedrock any approach to the obligations of corporations to monitor and control the behavior of others." 205

\footnotetext{
${ }^{199}$ Mapping Standards, supra note 112, para. 87.

${ }^{200}$ Corporate responsibility under international law and issues in extraterritorial regulation: summary of legal workshops, Addendum 2 to the Report, A/HRC/4/35/Add.2, 2007, para. 34. See also Evolving Agenda, supra note 37 , p. 839.

${ }^{201}$ See text associated with supra note 33.

${ }^{202}$ OECD Guidelines for Multinational Enterprises, supra note 105, p. 11.

${ }^{203}$ Ruggie, supra note 173.

${ }^{204}$ Evolving Agenda, supra note 37, p. 824.

${ }^{205}$ Catá Backer, supra note 194, p. 74.
} 
The question is whether Ruggie should have isolated, for reason of clarity, the case of business groups and networks as distinguished from individual enterprises, and then disaggregated the RtR to explain what it requires from core companies. ${ }^{206}$ Is the core company only under a responsibility to 'respect', asking it to make sure its decisions do not harm directly or indirectly human rights, or is it also under a responsibility to 'protect' the human rights that affiliates infringe? Without using these words, in his explanations and illustrations of due diligence Ruggie clearly covers both the 'respect' and 'protect' situations. This broad scope of the RtR is commendable and in tune with social expectations. But Ruggie chose not to come forward with a principled way of attributing responsibility to the core company in the 'protect' case. Conceptually, this is a question of attribution of responsibility well-known in jurisprudence in determinations of liability.

Ruggie did screen jurisprudence and explicitly took note of available legal doctrines. Overall Ruggie makes extensive use of the notion of complicity, in both its legal meaning (such as 'aiding and abetting') and a non-legal meaning (such as 'association' or 'involvement'). ${ }^{207}$ His 2007 report referred to some legal doctrines: "The international tribunals have also imposed liability for 'aiding and abetting' a crime, or for engaging in a 'common purpose' or 'joint criminal enterprise'." 208 In 2010 Ruggie further wrote:

[O]ne legal challenge is the attribution of responsibility among members of a corporate group. Many corporate-related human rights violations also violate existing national civil or criminal law, but applying those provisions to corporate groups can prove extremely complex, even in purely domestic cases. A range of legal arguments has been advanced in cases involving the responsibility of parent companies for harm caused by subsidiaries. Some rely on the parent company's alleged 'negligence' with respect to its subsidiary (primary liability), focusing, for example, on whether the parent has established key systems or processes, like those dealing with hazardous activities. Other arguments invoke 'complicity' (secondary liability) or the concept of 'agency' (vicarious or third party liability), which are found in both common and civil law jurisdictions. The responsibility of partners in joint ventures and other contractbased relationships raises even more complex questions, though the theory of multi-agency liability has gained traction in some jurisdictions. In short, far greater clarity is needed regarding the responsibility of corporate parents and groups for the purposes of remedy. ${ }^{209}$

However Ruggie covered jurisprudence only in a descriptive manner: doctrines were noted, their relevance acknowledged but not analytically distinguished from each other in order to settle conceptually the 'protect' scenario. Nor did he deem it necessary to settle the difficulty of attributing responsibility for purposes of his RtR. The problem, it can be safely said, is that the legal separation of entities is an unavoidable aspect whenever discussing the RtR of business groups. Ruggie is mindful of its crippling effects, wrote explicitly on it, but did not crack it conceptually. Instead he chose a subtle strategy of avoidance (presented it as an obstacle to access to remedies relevant to Pillar 3 instead of an issue of corporate responsibility in Pillar 2) and postponement (legal professionals and national legal systems deal with this obstacle) in the

\footnotetext{
${ }^{206}$ See chapter by Mares in this volume.

${ }^{207}$ He wrote: "The corporate responsibility to respect human rights includes avoiding complicity. The concept has legal and non-legal pedigrees, and the implications of both are important for companies. Complicity refers to indirect involvement by companies in human rights abuses - where the actual harm is committed by another party, including governments and non-State actors." Protect, Respect and Remedy, supra note 14, para. 73. See also Clarifying the Concepts of 'Sphere of influence' and 'Complicity', Companion report, A/HRC/8/16, 2008.

${ }^{208}$ Mapping Standards, supra note 112, para. 23.

${ }^{209}$ Further steps, supra note 78, paras. 105-106.
} 
context of his more general approach being principle-based (a foundational treatment with details to be spelled out later on) and not legalistic (no scheme for the attribution of liability is needed). In fairness, limited liability is a tough nut to crack, but remains inescapably relevant to future treatments of the RtR of large business groups and networks simply because "the corporation enjoys separate legal personhood [which is one of the] essential legal attributes of the corporate form of business organization". 210

As a result there is a possibility that the 'respect' aspect of Ruggie's RtR appears mandatory, imperative under the 'do no harm' principle, while the 'protect' aspect remains aspirational as it is grounded in something else than do no harm. ${ }^{211}$ That this aspirational element remains in Ruggie's RtR is remarkable given his principled rejection of the sweeping responsibilities proposed by the Draft Norms. The implications for the implementation of the RtR are particularly disturbing: when policy pronouncements endorsing Ruggie's RtR reach the ground, the RtR becomes atomised in the RtR of separated companies with no imperative on the core company to oversee and influence affiliates. One is pressed to admit then that such affirmations of responsibility can only be read, when it comes to the 'protect' component of the RtR, as aspirational, hortatory statements from policymakers well aware of the legal realities in their domestic systems. That is indeed a modest and limited treatment of the responsibility of business groups. Without that imperative character, and despite Ruggie's stated purpose of leveraging key players on the global governance stage, core companies are likely to recede in the background of the chess board that Ruggie masterly arranged.

Ruggie's conceptualisation of the RtR gave them this opportunity. It weakens calls for core companies to assume their responsibility to act when affiliates misbehave. They may be brought back to the forefront in a more ad hoc manner and on a voluntary basis through multistakeholder, public-private governance arrangements. Ruggie drew attention to this and also promoted the concept of 'shared responsibility'. Examples and lessons from supply chains make the point of shared responsibility forcefully. ${ }^{212}$

\subsubsection{Supply Chain Issues}

\footnotetext{
${ }^{210}$ Stevelman, supra note 77, p. 836. Stevelman further wrote that "the limited liability of corporate shareholders is valorized as a major driver of wealth creation ... after fifteen years of reflecting on cases in which the courts are called upon to pierce the corporate veil, I can find little depth of legal reasoning in them, beyond the policy goals of incentivizing capital formation and encouraging investment in the corporate form. In essence, the legal rule quite nakedly embraces a policy judgment that even tort creditors' claims will be subordinated to those goals. There appears to be no deeper intellectual coherence in the limited liability case law. The fact that corporate law privileges the goal of capital formation over the compensation of tort victims is certainly a topic of social relevance." Ibid., pp. 842-843 (reference omitted).

${ }^{211}$ Such uncertainties in Ruggie's treatment were pinpointed in the comments of the EU comments on the draft Guiding Principles. The EU referred to "areas where the Guiding Principles could be more precise ...: Clarification of the concept of responsibility within a corporate group would be useful ..." EU comments, supra note 25.
}

${ }^{212}$ UNCTAD referred to the imperative of building capacity for compliance in supply chains that would require from the buyer companies a strategy of 'shared responsibility' as opposed to 'offloading responsibility' on the suppliers. United Nations Conference on Trade and Development (UNCTAD), 2011 World Investment Report (United Nations, 2011), p. 117. 
Back in the mid-1990s the media uncovered sweatshop practices in factories producing for famous global brands such as the market-leader Nike. ${ }^{213}$ A stream of similar stories continues to this day. ${ }^{214}$ Civil society put pressure on buyer companies to accept responsibility for workers' rights throughout their supply chains, and not few companies have done so. ${ }^{215}$ After 15 years, it is time to take stock and learn the lessons of what works effectively and efficiently and what does not. $^{216}$

At one of the seminars convened by the SRSG, "[p] articipants were unanimous that change has to be systemic, not piecemeal or one-off. They suggested that a 'long fix' - as opposed to a 'quick fix' - was required". ${ }^{217}$ The elements of a 'long fix' were identified to include empowering workers, building the capacity of suppliers, changing buyer's policies and practices, and building the capacity of labour inspectorates. ${ }^{218}$ On a likeminded tone, the trade union view has consistently been that

[i]nstead of playing cat and mouse, these companies are starting to get to the root causes of problems and deliver more sustainable supply chains ... The current approach is simply not sustainable in the longer term. It needs to be replaced by a mature system of industrial relations based on social dialogue where representatives of management and workers become daily monitors of workplace situations. ${ }^{219}$

Sometimes the solution to rights violations in the value chain seems easier, at least conceptually. This is the case of goods that can be boycotted and prevented from reaching markets. The Kimberley Process - the public-private governance arrangement to prevent conflict diamonds from reaching international markets - is a well-known example. More recently, cotton harvested in Uzbekistan with the use of forced child labour is being subjected to a private boycott. The civil society group Responsible Sourcing Network was joined by large retailers such as Walmart and Macy's and by TNCs such as Nike and Liz Claiborne in a signed pledge to boycott Uzbek cotton. This group of 70 companies demands that the government stops using forced child labour to harvest its cotton crops. ${ }^{220}$ Also a recent story featured a company, Danish-based Lundbeck,

\footnotetext{
${ }^{213}$ Referring to that moment in time, Ruggie observed that " $[\mathrm{t}]$ he issue of business and human rights burst into global public consciousness in the 1990s. Some of the early cases have acquired iconic status: Shell accused of complicity for standing by silently as the Nigerian military government executed a leader of community groups demonstrating against the company's environmental degradation of the Delta region; BP accused of being responsible for alleged acts of murder, disappearances, torture, rape, and forced displacement of communities by a Colombian army brigade protecting its installation; allegations of sweatshop conditions and child labor in Nike's Indonesian, and the GAP's Salvadorian, suppliers.” J. G. Ruggie, Next steps in business and human rights, Remarks at Royal institute of international affairs, Chatham house, London, 22 May 2008, <www.reports-andmaterials.org/Ruggie-speech-Chatham-House-22-May-2008.pdf>.

214 'Fashion chain Zara acts on Brazil sweatshop conditions', BBC, 18 august 2011, <www.bbc.co.uk/news/worldlatin-america-14570564>. Ripe with Abuse: Human Rights Conditions in South Africa's Fruit and Wine Industries, Human Rights Watch, 23 August 2011, <www.hrw.org/reports/2011/08/23/ripe-abuse-0>.

${ }^{215}$ For multistakeholder initiatives dedicated to labour standards in supply chains, see those of the Fair Labor Association, Social Accountability International, and Ethical Trading Initiative.

${ }^{216}$ See the chapters by Lukas, and Skadegaard Thorsen and Andreasen in this volume.

${ }^{217}$ Summary of five multi-stakeholder consultations, supra note 146, para. 246.

${ }^{218}$ Ibid.

${ }^{219}$ R. Wilshaw, 'Social audits flawed as a way of driving sustainable change', The Guardian, 12 July 2011, <www.guardian.co.uk/sustainable-business/blog/social-audits-flawed-companies-developing-world>.

${ }^{220}$ K. Kattalia, 'Retailers such as Nike and Macy's boycott cotton from Uzbekistan to protest child labor', Daily News Writer, 7 July 2011, <www.nydailynews.com/lifestyle/fashion/2011/07/07/2011-07-

07_retailers_boycott_cotton_from_uzbekistan_to_protest_child_labor.html >.
} 
which decided to act to prevent its products from being used by third parties to infringe rights. The company took steps to prohibit its drugs from being used to execute convicts in the US. According to Lundbeck policy, "[p]urchasers will have to sign a form affirming the drug is for their own use and will not be used for capital punishment and that they will not re-distribute the drug without the company's approval".221

But often the solution to abuses in value chains is clearly broader than a single-minded emphasis on buyer responsibility and often requires multistakeholder governance arrangements at different levels. ${ }^{222}$ One such example with potential to protect rights sustainably and effectively comes from Indonesia where labour unions, major supplier factories and key sportswear brands have agreed to guarantee freedom to form unions and bargain collectively. ${ }^{223}$ The role of the buyer company remains essential to solve other difficult issues, such as that of worker remuneration. Recently the NGO ActionAid hailed British retailer Marks and Spencer as the first retailer to commit itself to ensuring living wages for suppliers' employees. ${ }^{224}$ The company promised to "[i]mplement a process to ensure our clothing suppliers are able to pay workers a fair 'living' wage in the least developed countries we source from, starting with Bangladesh, India and Sri Lanka by 2015. We will achieve this by ensuring that the cost prices we pay to our suppliers are adequate to pay a fair living wage and by rolling out our ethical model factory programme."225

Another difficult area refers to sourcing raw materials from conflict zones. The OECD dedicated a detailed guidance document aimed at securing human rights in conflict-affected and high-risk areas where minerals are sourced from. Due diligence steps are identified to trace minerals, and prevent and mitigate risks of human rights abuses. ${ }^{226}$ The OECD outlook is premised on the realisation that "governments, international organisations and companies can each draw on their respective competences and roles to contribute to ensuring that trade and investment in natural resources is beneficial to society at large". ${ }^{227}$

\section{Conclusion}

\footnotetext{
221 'Virginia executes Jerry Jackson amid death-drug row', $B B C, 19$ august 2011, <www.bbc.co.uk/news/world-uscanada-14579136>. Reprieve, the London-based rights group that sought the ban, welcomed the news. "Lundbeck has proven that manufacturers can control the use and distribution of their drugs. Any company manufacturing execution drugs who refuses to take such steps will be directly complicit in executions ... Other pharmaceutical companies should now follow Lundbeck's example." A. Gabbatt and D. Batty, 'Danish firm Lundbeck to stop US jails using drug for lethal injections', The Guardian, 1 July 2011.

${ }_{222}$ See the chapter by Skadegaard Thorsen and Andreasen in this volume.

${ }^{223}$ O.Tudor, 'Adidas, Nike and Puma sign up with unions on Indonesian textile worker rights', Blog, 7 June 2011. See fulltext of the signed Freedom of Association Protocol at <play-fair.org/media/wp-content/uploads/FOAProtocol_English-translation_May-20112.pdf $>$.

${ }^{224}$ ActionAid, Tax responsibility - The business case for making tax a corporate responsibility issue, 2011, p. 7, <www.actionaid.org.uk/doc_lib/tax_responsibility.pdf>.

${ }^{225}$ Objective 17 (Ensure workforces and communities benefit in our supply chain). Marks \& Spencer, How we do business report, 2010, p. 47, <plana.marksandspencer.com/media/pdf/planA-2010.pdf>.

${ }^{226}$ The Guidance recommends companies to commit themselves and orient there due diligence towards the following goal: "Regarding serious abuses associated with the extraction, transport or trade of minerals, [w]hile sourcing from, or operating in, conflict-affected and high-risk areas, we will neither tolerate nor by any means profit from, contribute to, assist with or facilitate the commission." Annex II, Model Supply Chain Policy, OECD, supra note 106.

${ }^{227}$ OECD, supra note 106, p. 7.
} 
In June 2011, the group of states (the 'Core sponsors') drafting the resolution to be adopted by the Human Rights Council recalled the complex and deeply divisive history of CSR in the UN and appreciated the "incremental approach so successfully carved out by Professor Ruggie". 228 In an interview around the same time, Ruggie declared that "[h]istory marches in small steps, but to lay the foundation of future developments is an important first step ... We now have a uniform platform; a uniform foundation on which to build going forward." 229 Several key issues highlighted in this chapter were left in suspension because of a lack of consensus in the legal community (i.e. extraterritoriality), the issue appeared intractable (i.e. legal separation of entities) or the complexity was overwhelming (i.e. responsibilities of actors in financial markets). In such cases more daring treatments from the SRSG side would have run the risk of backfiring. There is little doubt that legal departments in companies and governments are able and ready to pick on controversial positions and question the rigour of the entire work.

Aiming to facilitate a process where cumulative progress can be achieved, Ruggie left it to the follow-up process in the UN and elsewhere to push rule-making further. Further clarifications of the principles Ruggie outlined will be needed. Frankental's thoughts are relevant for grasping the task lying ahead for the academia and human right law experts: he considered that "a key challenge for Amnesty International in reshaping its business and human rights work will be to integrate human rights into other disciplines that also seek to raise standards for companies". 230 As for Ruggie, who will remain involved in the business and human rights movement, he looked back to his mandate and said: "Dealing with all rights; all states; all businesses, national and transnational, large and small; and getting all of that diversity into a simple and coherent Framework, with guidance on how it should be implemented, was both intellectually and politically challenging."231

\footnotetext{
${ }^{228}$ Introduction of draft resolution L17: Human Rights and transnational corporations and other business enterprises, 17th session of the Human Rights Council, 2011, <www.businesshumanrights.org/media/documents/ruggie/statements-norway-uk-business-human-rights-16-jun-2011.pdf> .

${ }^{229}$ U. Mast-Kirschning, 'States, companies must ensure human rights, UN expert says', Interview with John Ruggie, Deutsche Welle, 20 June 2011, <www.dw-world.de/dw/article/0,,15173983,00.html>.

${ }^{230}$ P. Frankental, The Reshaping of Amnesty International's Business and Human Rights Work, Institute for Human Rights and Business, 18 May 2011, <www.ihrb.org/commentary/guest/amnesty_international_business_human_rights.html>.

${ }^{231}$ Interview, supra note 26.
} 


\section{Annex 1: Reports of the Special Representative of the Secretary-General on the issue of human rights and transnational corporations and other business enterprises, John Ruggie*}

Interim Report of the Special Representative of the Secretary-General on the Issue of Human Rights and Transnational Corporations and Other Business Enterprises, E/CN.4/2006/97, 2006.

Business and Human Rights: Mapping International Standards of Responsibility and Accountability for Corporate Acts, A/HRC/4/035, 2007.

State responsibilities to regulate and adjudicate corporate activities under the United Nations core human rights treaties: an overview of treaty body commentaries, Addendum 1 to the Report, A/HRC/4/35/Add.1, 2007.

Corporate responsibility under international law and issues in extraterritorial regulation: summary of legal workshops, Addendum 2 to the Report, A/HRC/4/35/Add.2, 2007.

Human Rights Policies and Management Practices: Results from questionnaire surveys of Governments and Fortune Global 500 firms, Addendum 3 to the Report, A/HRC/4/35/Add.3, 2007.

Business recognition of human rights: Global patterns, regional and sectoral variations, Addendum 4 to the Report, A/HRC/4/35/Add.4, 2007.

Human rights impact assessments - resolving key methodological questions, Companion report, A/HRC/4/74, 2007.

Protect, Respect and Remedy: a Framework for Business and Human Rights, A/HRC/8/5, 2008.

Clarifying the Concepts of "Sphere of influence" and "Complicity", Companion report, A/HRC/8/16, 2008.

Summary of five multi-stakeholder consultations, Addendum 1 to the Report, A/HRC/8/5/Add.1, 2008.

Corporations and human rights: a survey of the scope and patterns of alleged corporate-related human rights abuse, Addendum 2 to the Report, A/HRC/8/5/Add.2, 2008.

Business and human rights: Towards operationalizing the "protect, respect and remedy" framework, A/HRC/11/13, 2009.

Business and Human Rights: Further steps toward the operationalization of the "protect, respect and remedy" framework, A/HRC/14/27, 2010. 
Guiding Principles on Business and Human Rights: Implementing the United Nations "Protect, Respect and Remedy" Framework, A/HRC/17/31, 2011.

Piloting principles for effective company/stakeholder grievance mechanisms: A report of lessons learned, Addendum 1 to the Report, A/HRC/17/31/Add.1, 2011.

Human rights and corporate law: trends and observations from a crossnational study conducted by the Special Representative, Addendum 2 to the Report, A/HRC/17/31/Add.2, 2011.

Principles for responsible contracts: integrating the management of human rights risks into Stateinvestor contract negotiations: guidance for negotiators, Addendum 3 to the Report, A/HRC/17/31/Add.3, 2011.

Business and human rights in conflict-affected regions: challenges and options towards State responses, Companion report, A/HRC/17/32, 2011.

* Note. See also a comprehensive List of documents prepared by and submitted to the SRSG at <www.reports-and-materials.org/Ruggie-docs-list.pdf>. 


\section{Annex 2: Resolutions of the Commission on Human Rights and Human Rights Committee relevant to the SRSG mandate}

Commission on Human Rights, Responsibilities of transnational corporations and related business enterprises with regard to human rights, Decision 2004/116, 2004.

Commission on Human Rights, Human rights and transnational corporations and other business enterprises, Resolution 2005/69, 2005.

Human Rights Council, Mandate of the Special Representative of the Secretary-General on the issue of human rights and transnational corporations and other business enterprises, Resolution $8 / 7,2008$.

Human Rights Council, Human rights and transnational corporations and other business enterprises, A/HRC/17/L.17/Rev.1, 2011. 